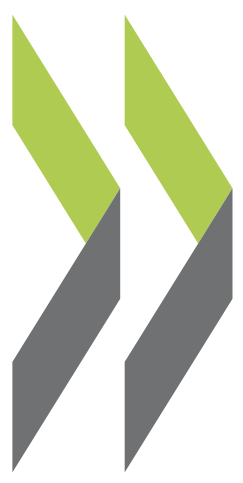

\title{
Assessing China's skills gap and inequalities in education
}

Margit Molnar, Boqing Wang, Ruidong Gao 


\section{Unclassified}

ECO/WKP(2015)38

Organisation de Coopération et de Développement Économiques

Organisation for Economic Co-operation and Development

22-May-2015

ECONOMICS DEPARTMENT

English - Or. English

\section{ASSESSING CHINA'S SKILLS GAP AND INEQUALITIES IN EDUCATION}

ECONOMICS DEPARTMENT WORKING PAPERS No. 1220

By Margit Molnar, Boqing Wang and Ruidong Gao

OECD Working Papers should not be reported as representing the official views of the OECD or of its member countries. The opinions expressed and arguments employed are those of the author(s).

Authorised for publication by Robert Ford, Deputy Director, Country Studies Branch, Economics Department.

All OECD Economics Department Working Papers are available at www.oecd.org/eco/workingpapers

JT03377011

Complete document available on OLIS in its original format

This document and any map included herein are without prejudice to the status of or sovereignty over any territory, to the delimitation of international frontiers and boundaries and to the name of any territory, city or area. 
OECD Working Papers should not be reported as representing the official views of the OECD or of its member countries. The opinions expressed and arguments employed are those of the author(s).

Working Papers describe preliminary results or research in progress by the author(s) and are published to stimulate discussion on a broad range of issues on which the OECD works.

Comments on Working Papers are welcomed, and may be sent to the Economics Department, OECD, 2 rue André-Pascal, 75775 Paris Cedex 16, France, or by e-mail to eco.contact@ oecd.org.

This document and any map included herein are without prejudice to the status of or sovereignty over any territory, to the delimitation of international frontiers and boundaries and to the name of any territory, city or area.

The statistical data for Israel are supplied by and under the responsibility of the relevant Israeli authorities. The use of such data by the OECD is without prejudice to the status of the Golan Heights, East Jerusalem and Israeli settlements in the West Bank under the terms of international law.

C OECD (2015)

You can copy, download or print OECD content for your own use, and you can include excerpts from OECD publications, databases and multimedia products in your own documents, presentations, blogs, websites and teaching materials, provided that suitable acknowledgment of OECD as source and copyright owner is given. All requests for commercial use and translation rights should be submitted to rights@oecd.org 
ECO/WKP(2015)38

\section{ABSTRACT/RÉSUMÉ}

\section{Assessing China's skills gap and inequalities in education}

In recent years, many tertiary graduates have had difficulties finding a job, while factories have been struggling to recruit workers. Notwithstanding rapidly increasing education attainment, graduates' skills do not seem to match those demanded by the market. Moreover, structural changes in the economy aggravate the shortage of skills in newly emerging industries. While the problem is widely recognised, empirical studies of the issue are scarce and the skills gap has not been quantified. This paper aims at gaging the skills and knowledge gap of tertiary graduates of universities and vocational colleges across China. It also looks at the employment and wage prospects of graduates with different educational backgrounds.

Inequalities in educational opportunities, stemming in particular from the urban-rural divide and to a lesser extent from the social background, shape careers and lives. The best primary and middle schools are located in the biggest cities and until recently children competed for a place at such schools. In third and fourth-tier cities or in rural areas, in contrast, there are fewer choices and thus less chance to get into a "model" high school or a top university. The family background also tends to have an impact on the choice of a school or profession and on future earnings. This paper discusses various aspects of inequalities related to the place of upbringing, family background and geographical area. Micro-level data analysis is complemented by an investigation into inequalities of various aspects of education at the city and county levels.

This Working Paper relates to the 2015 OECD Economic Survey of China

www.oecd.org/eco/surveys/economic-survey-china.htm

JEL classification: J24, H52, I23, I24.

Keywords: China, skills mismatch, university graduates, vocational college, inequality, educational opportunity, urban-rural divide, family background, government spending.

\section{Évaluation du déficit de qualifications en Chine et inégalités du système éducatif}

Depuis quelques années, de nombreux diplômés de l'enseignement supérieur éprouvent des difficultés à trouver un emploi tandis que les usines peinent à recruter de la main-d'œuvre. En dépit d'un relèvement rapide des niveaux d'instruction, il ne semble pas que les qualifications des diplômés correspondent aux besoins du marché. Qui plus est, les mutations structurelles de l'économie aggravent le déficit de qualifications dans les industries nouvelles qui voient le jour. Si le problème est largement admis, les études empiriques sur le sujet ne sont pas légion et le déficit de qualifications n'a pas été quantifié. Ce document de travail a pour but d'évaluer le déficit de qualifications et de connaissances des diplômés des universités et des instituts professionnels de l'enseignement supérieur en Chine. Il examine également les perspectives d'emploi et de rémunération des diplômés issus de différentes filières de formation.

Les vies et les carrières en Chine sont le reflet des inégalités d'accès au système éducatif, qui découlent notamment de la fracture entre les zones urbaines et rurales, mais aussi, dans une moindre mesure, de l'origine sociale. Les meilleurs établissements d'enseignement primaire et secondaire (collèges) se situent dans les plus grandes villes du pays et il y peu de temps encore, la concurrence était âpre pour s'y inscrire. En revanche, dans les villes de troisième et quatrième rangs, ou dans les zones rurales, l'offre est moins abondante et les chances d'intégrer un lycée «modèle » ou une université réputée sont d'autant plus réduites. Le milieu familial tend également à avoir un impact sur le choix d'une école ou d'une profession et sur la rémunération future. Ce document de travail examine ces inégalités sous l'angle du lieu d'éducation, de l'origine familiale et de la zone géographique des élèves. Un examen des inégalités de divers aspects du système éducatif, au niveau des villes et des comtés, complète l'analyse des micro-données.

Ce document de travail se rapporte à l'Étude économique de la Chine, OCDE, 2015 www.oecd.org/fr/eco/etudes/etude-economique-chine.htm.

Classification JEL : J24, H52, I23, I24,

Mots-clés : Chine, déficit de qualifications, diplômés des universités, instituts professionnels, inégalité, accès au système éducatif, fracture entre zones urbaines et rurales, milieu familial, dépenses publiques. 


\title{
TABLE OF CONTENTS
}

\author{
ASSESSING CHINA'S SKILLS GAP AND INEQUALITIES IN EDUCATION ....................................

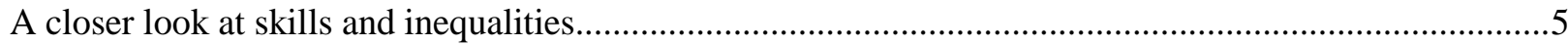

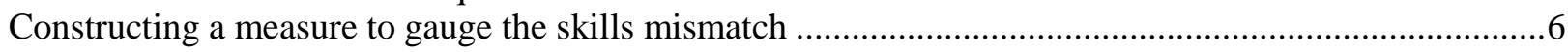

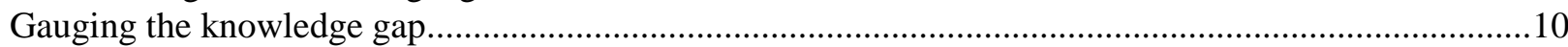

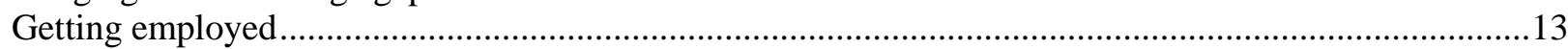 \\ Mismatches cause a sizeable share of graduates to take up jobs unrelated to their studies ...................14

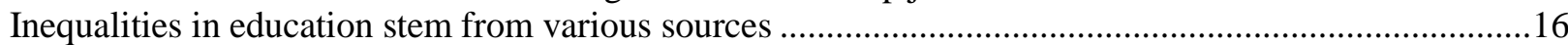 \\ The family/social background matters for schooling, but once one receives tertiary education, less so

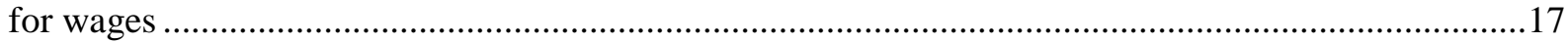

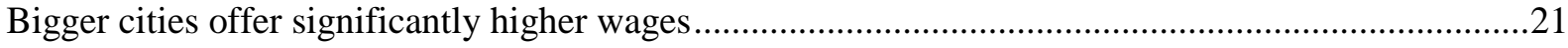

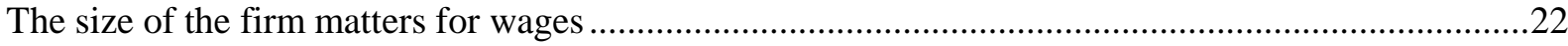 \\ Education-related inequalities tend to be relatively small at the city and county levels .......................23 \\ Looking ahead: filling the skills gap and reducing inequalities...........................................................25
}

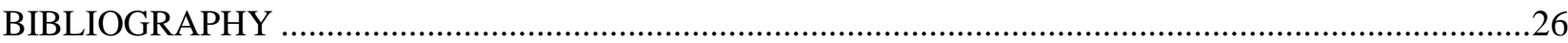

\section{Tables}

1. Practical skills including programming are most important for jobs

2. Among both university and vocational college graduates, the skills gap is largest in programming9

3. Among university graduates, the knowledge gap is largest in sales and marketing, HR and

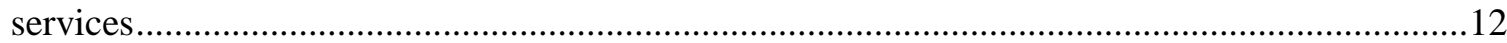

4. The knowledge gap is greatest in among vocational college graduates....................................13

5. Many graduates fail to meet the requirements for jobs related to their majors .............................15

6. Unfulfilled career hopes are the main reason for dissatisfaction with jobs among university

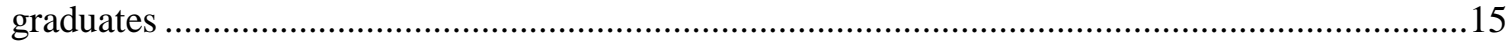

7. A large share of vocational college graduates find their jobs far from what they expected ..........16

8. Quit rates are high among vocational college graduates.............................................................16

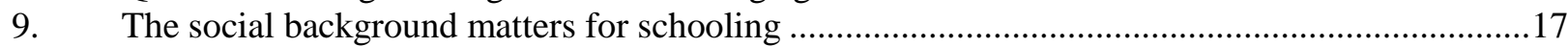

10. Vocational college graduates tend to have parents with lower educational attainment .................18

11. Children of university graduates are more likely to go to the top universities ............................18

12. Determinants of wages differ along the wage distribution and between university and vocational

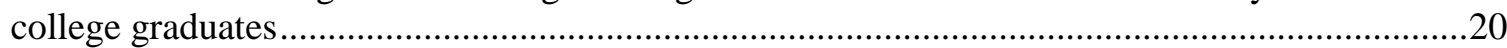

13. The four municipalities offer $20-30 \%$ higher wages than small cities or rural areas....................21

14. Earning prospects three years after graduation are brighter in megacities..................................21

15. Many graduates take up a position in the city where they studied.............................................22

16. Mega-firms pay roughly a third more than small firms ....................................................23

17. Inequalities at the city level are relatively small in most education-related indicators..................24

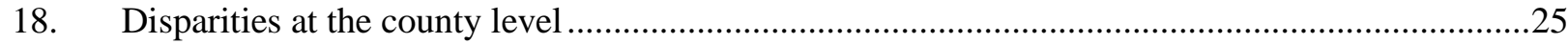

Figures

1. Programming as well as management and other soft skills are falling short ................................

2. Service-related training is not meeting labour market needs ...................................................11 
ECO/WKP(2015)38

\title{
ASSESSING CHINA'S SKILLS GAP AND INEQUALITIES IN EDUCATION
}

\author{
By Margit Molnar, Boqing Wang and Ruidong Gao ${ }^{1}$
}

\section{A closer look at skills and inequalities}

1. In recent years, many tertiary graduates have had difficulties finding a job, while factories have been struggling to recruit workers. Notwithstanding rapidly increasing education attainment, graduates' skills do not seem to match those demanded by the market (OECD, 2015). Moreover, structural changes in the economy aggravate the shortage of skills in newly emerging industries. While the problem is widely recognised, empirical studies of the issue are scarce and the skills gap has not been quantified. This paper aims at gaging the skills and knowledge gap of tertiary graduates of universities and vocational colleges across China. It also looks at the employment and wage prospects of graduates with different educational backgrounds.

2. Inequalities in educational opportunities, stemming in particular from the urban-rural divide and to a lesser extent from the social background, shape careers and lives. The best primary and middle schools are located in the biggest cities and until recently children competed for a place at such schools. In third and fourth-tier cities or in rural areas, in contrast, there are fewer choices and thus less chance to get into a "model" high school or a top university. The family background also tends to have an impact on the choice of a school or profession and on future earnings. This paper discusses various aspects of inequalities related to the place of upbringing, family background and geographical area.

3. Most data used in this paper come from the MyCOS (My China Occupational Skills) database, in particular from two surveys. The Six Months Postgraduate College Employment \& Education Quality Follow-up Evaluation focuses on the demand for and education quality of graduates six months after graduation, and is conducted yearly in March. The College Graduate Mid-Term Career Development Evaluation surveys the same pool of graduates three years after graduation; it is conducted yearly in February. Both surveys cover 31 provinces, municipalities and autonomous regions in China and have been stratified for majors, occupations, industries, school type, urban areas, and family socioeconomic class. For the purposes of this report, the following samples were analysed: 786000 individual data across the classes of 2011, 2012 and 2013 from the six months postgraduate evaluation, and 98000 individual data across the classes of 2009 and 2010 from the mid-term evaluation. These original data were then

1. Margit Molnar heads the China desk in the OECD Economics Department and Dr. Boqing Wang is Director of Research, My China Occupational Skills (MyCOS) in Beijing. Ruidong Gao was a consultant on the China desk at the time of writing. This paper was originally produced as a background document for the 2015 OECD Economic Survey of China published in March 2015 under the authority of the Economic and Development Review Committee (EDRC). The authors thank Alvaro Pereira, Robert Ford, Vincent Koen, Ben Westmore, Elizabeth Fordham as well as officials from the Chinese government for valuable comments on earlier drafts, and Thomas Chalaux for statistical and Nadine Dufour for editorial assistance. 
stratified by majors, occupations, industries, school types, urban areas and family socioeconomic classes to obtain a representative national dataset, which is used directly in the analyses.

4. Survey respondents are graduates of Project 211 universities, non-Project 211 four-year universities, vocational colleges, and vocationally oriented departments of four-year universities. "211" universities represent around 100 top institutions to train talents for the 21 st century and non-" 211 " universities are the remaining nearly 1000 institutions. Not included are graduates from institutions of continuing education and universities in Hong Kong, China; Macao, China and Chinese Taipei. MyCOS sends a unique link to tertiary institution graduates, who, upon completion, receive a customised report analysing their employment situation and skills/knowledge relative to peers in their same industry and occupation. Each survey takes on average 15 to 30 minutes to complete.

5. Micro-level data analysis based on the MyCOS database is complemented by an investigation into inequalities of various aspects of education at the city and county levels based on National Bureau of Statistics data from CEIC. Policy analyses and recommendations on how to fill the skills gap and how to reduce inequalities in the 2015 OECD Economic Survey of China (OECD, 2015).

\section{Constructing a measure to gauge the skills mismatch}

6. The skills mismatch, defined as the difference between skills demanded by employers and those available in the market, can be captured using the MyCOS survey data based on the answers of over 150000 graduates in 2013, six months after graduation. The survey asked graduates to judge whether a certain skill type is important for their job, whether it is necessary to perform their job and whether they acquired that skill by the time they graduated. The 35 skills are classified into five broader categories: practical, analytical, managing, critical thinking and understanding and communication (Table 1).

7. When ranking skills by importance, soft skills such as management and communications ranked among the top ones. For university graduates, speaking, negotiation, persuasion and active learning are considered more important than practical skills such as programming. Vocational college graduates rank programming first, but the following skills in the ranking are similar to those of university graduates: speaking, negotiation, persuasion and judgement and decision making. Maths, monitoring and repairing are considered by both types of graduates among the least important skills in the present marketplace. 
ECO/WKP(2015)38

Table 1. Practical skills including programming are most important for jobs

Percentage of graduates six months after graduation, 2013

\begin{tabular}{|c|c|c|c|c|c|c|c|}
\hline \multirow[b]{2}{*}{ Skill type } & \multirow[b]{2}{*}{ Skill } & \multicolumn{3}{|c|}{$\begin{array}{c}\text { University } \\
\text { (2013 graduates) }\end{array}$} & \multicolumn{3}{|c|}{$\begin{array}{r}\text { Vocational college } \\
\text { (2013 graduates) }\end{array}$} \\
\hline & & $\begin{array}{l}\text { Impor- } \\
\text { tance }\end{array}$ & $\begin{array}{l}\text { Acqui- } \\
\text { red }\end{array}$ & $\begin{array}{l}\text { Neces } \\
\text { sity }\end{array}$ & $\begin{array}{l}\text { Impor- } \\
\text { tance }\end{array}$ & $\begin{array}{l}\text { Acqui- } \\
\text { red }\end{array}$ & $\begin{array}{l}\text { Impor- } \\
\text { tance }\end{array}$ \\
\hline Practical & Programming & 74 & 49 & 71 & 74 & 48 & 70 \\
\hline Practical & Installation & 62 & 43 & 59 & 62 & 48 & 61 \\
\hline Practical & Repairing & 57 & 42 & 59 & 60 & 47 & 62 \\
\hline Analytical & Troubleshooting & 74 & 51 & 66 & 69 & 51 & 64 \\
\hline Analytical & Systems analysis & 71 & 44 & 63 & 61 & 51 & 62 \\
\hline Analytical & Technology design & 69 & 50 & 66 & 69 & 49 & 66 \\
\hline Analytical & Quality control analysis & 67 & 47 & 60 & 62 & 49 & 60 \\
\hline Analytical & Operation and control & 67 & 44 & 60 & 63 & 49 & 61 \\
\hline Analytical & Operation monitoring & 66 & 43 & 64 & 57 & 51 & 64 \\
\hline Analytical & Operations analysis & 64 & 55 & 68 & - & - & - \\
\hline Analytical & Equipment maintenance & 63 & 46 & 62 & 60 & 47 & 62 \\
\hline Analytical & Equipment selection & 57 & 52 & 63 & 53 & 49 & 59 \\
\hline Analytical & Systems evaluation & - & - & - & 51 & 54 & 57 \\
\hline Managing & Negotiation & 76 & 41 & 56 & 73 & 42 & 52 \\
\hline Managing & Persuasion & 75 & 46 & 64 & 73 & 46 & 62 \\
\hline Managing & Time management & 70 & 49 & 57 & 68 & 54 & 59 \\
\hline Managing & Coordination & 70 & 54 & 64 & 65 & 53 & 62 \\
\hline Managing & Complex problem solving & 69 & 51 & 62 & 68 & 50 & 59 \\
\hline Managing & Instructing & 69 & 53 & 61 & 65 & 52 & 57 \\
\hline Managing & Management of personnel resources & 68 & 42 & 59 & 66 & 44 & 59 \\
\hline Managing & Judgment and decision making & 67 & 49 & 61 & 70 & 50 & 61 \\
\hline Managing & Management of financial resources & 64 & 48 & 57 & 59 & 46 & 54 \\
\hline Managing & Management of material resources & 63 & 42 & 51 & 58 & 46 & 54 \\
\hline Managing & Monitoring & 55 & 52 & 59 & 61 & 53 & 61 \\
\hline Critical thinking & Writing & 67 & 54 & 69 & 59 & 56 & 64 \\
\hline Critical thinking & Science & 67 & 52 & 64 & 62 & 52 & 63 \\
\hline Critical thinking & Critical thinking & 60 & 54 & 62 & 59 & 55 & 62 \\
\hline Critical thinking & Mathematics & 38 & 51 & 53 & 38 & 51 & 56 \\
\hline Understanding and communication & Speaking & 77 & 53 & 65 & 74 & 52 & 62 \\
\hline Understanding and communication & Active learning & 75 & 54 & 66 & 70 & 53 & 63 \\
\hline Understanding and communication & Service orientation & 72 & 54 & 66 & 66 & 54 & 62 \\
\hline Understanding and communication & Active listening & 72 & 58 & 67 & 69 & 57 & 65 \\
\hline Understanding and communication & Social perceptiveness & 71 & 57 & 65 & 67 & 55 & 63 \\
\hline Understanding and communication & Learning strategies & 70 & 56 & 67 & 66 & 54 & 64 \\
\hline Understanding and communication & Reading comprehension & 65 & 60 & 67 & 62 & 59 & 65 \\
\hline Practical & Programming & 74 & 49 & 71 & 74 & 48 & 70 \\
\hline
\end{tabular}

Note: Importance: The graduates choose whether the given skill is important for their job. Acquired skill level: the share of graduates having the given skill when they graduated. Level 1 is the lowest and level 7 the highest. The graduates choose the given skill level they had when they graduated. Here the value of level 1 is defined as $1 / 7$, the value of level 2 as $2 / 7$, and so on. Necessity skill level: the share of graduates feeling the necessity of the given skill. Level 1 is the lowest and level 7 the highest. The graduates choose the given skill necessity level they felt during work. Here the value of level 1 is defined as $1 / 7$, the value of level 2 as $2 / 7$, and so on.

Source: Authors' analyses based on MyCOS survey data.

8. The skills acquired by the time of graduation do not appear to match the skills necessary to perform the job. The difference between the self-reported acquired skills at the time of graduation and the skills needed in their job six months after graduation provides a gauge of the mismatch in the graduate labour market. More specifically, the difference between the averages (weighted by the skill level) of the extent of necessity and the extent of acquired skills at school captures the skills gap. According to this measure, university graduates experienced the greatest mismatch in programming, followed by persuasion, management of personnel resources, operations analysis, operation monitoring and negotiation (Figure 1 and Table 2). Vocational college graduates also felt their programming skills deficit is the most acute, followed by persuasion, management of personnel resources, technology design and equipment maintenance. 
Figure 1. Programming as well as management and other soft skills are falling short

Percentage of university graduates in the top ten skill categories with the greatest gap, 2013

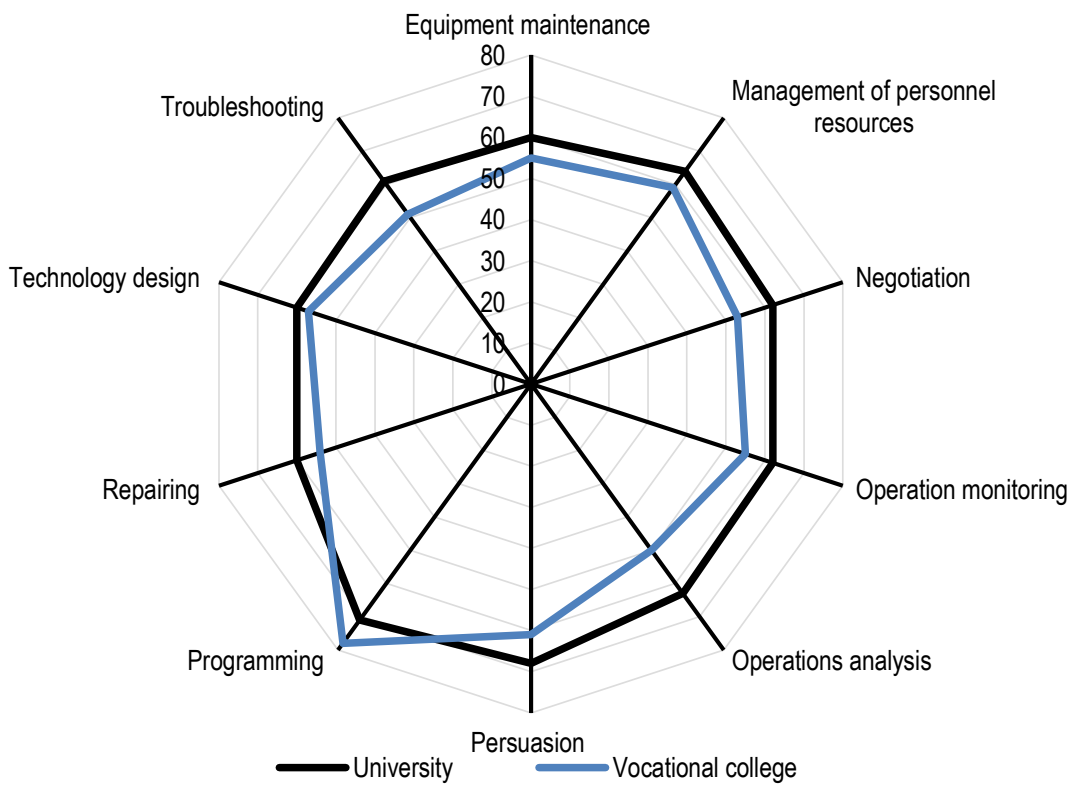

Note: University and vocational college graduates who had a job six months after graduation were asked whether the 5 skill categories out of 35 that are related to their job are necessary to perform their job (scale 1-7) and whether they had acquired the given skill by the time of graduation (scale 1-7). The difference between the weighted averages of the extent of necessity and the extent of acquired skills at school captures the skill gap. The ranking is based on the results for university graduates. Vocational college graduate skill shortages in the same skill categories are shown for comparison.

Source: Authors' analyses based on MyCOS survey data.

9. In some skill categories, such as maths, reading comprehension, monitoring, instructing and equipment selection, less than half of university graduates think they have not acquired adequate skills at university to perform their job (Table 2). Besides, in some of these categories and in financial and material resource management some feel that owing to low requirements, they do not make use of those skills in their daily assignments. Surprisingly, graduates of vocational schools give very similar answers, suggesting that areas of skills shortages are not specific to certain school types. 
ECO/WKP(2015)38

Table 2. Among both university and vocational college graduates, the skills gap is largest in programming

\begin{tabular}{|c|c|c|c|}
\hline \multicolumn{4}{|c|}{ A. Percentage of university graduates reporting shortage of skills, 2013} \\
\hline Skill & Shortage & Adequate & Surplus \\
\hline Reading comprehension & 41 & 42 & 17 \\
\hline Active listening & 49 & 40 & 11 \\
\hline Writing & 58 & 34 & 8 \\
\hline Speaking & 58 & 33 & 9 \\
\hline Mathematics & 31 & 47 & 22 \\
\hline Science & 53 & 39 & 8 \\
\hline Critical thinking & 49 & 41 & 10 \\
\hline Active learning & 56 & 32 & 12 \\
\hline Learning strategies & 53 & 37 & 10 \\
\hline Monitoring & 42 & 47 & 11 \\
\hline Social perceptiveness & 47 & 40 & 13 \\
\hline Coordination & 50 & 38 & 12 \\
\hline Persuasion & 68 & 27 & 5 \\
\hline Negotiation & 62 & 32 & 6 \\
\hline Instructing & 45 & 44 & 11 \\
\hline Service orientation & 53 & 37 & 10 \\
\hline Complex problem solving & 52 & 39 & 9 \\
\hline Operations analysis & 63 & 27 & 10 \\
\hline Technology design & 60 & 33 & 7 \\
\hline Equipment selection & 47 & 44 & 9 \\
\hline Installation & 57 & 36 & 7 \\
\hline Programming & 71 & 23 & 6 \\
\hline Quality control analysis & 56 & 35 & 9 \\
\hline Operation monitoring & 62 & 31 & 7 \\
\hline Operation and control & 57 & 36 & 7 \\
\hline Equipment maintenance & 60 & 33 & 7 \\
\hline Troubleshooting & 61 & 32 & 7 \\
\hline Repairing & 60 & 33 & 7 \\
\hline Systems analysis & 60 & 33 & 7 \\
\hline Systems evaluation & 52 & 45 & 3 \\
\hline Judgment and decision making & 52 & 38 & 10 \\
\hline Time management & 48 & 39 & 13 \\
\hline Management of financial resources & 49 & 38 & 13 \\
\hline Management of material resources & 48 & 38 & 14 \\
\hline Management of personnel resources & 64 & 28 & 8 \\
\hline
\end{tabular}

Note: University graduates who had a job six months after graduation were asked whether the 5 skill categories out of 35 that are related to their job are necessary to perform their job (scale 1-7) and whether they had acquired the given skill by the time of graduation (scale 1-7). The difference between the weighted averages of the extent of necessity and the extent of acquired skills at school captures the skills gap or surplus. When the weighted averages of necessary and acquired skills are equal, skills are considered adequate. 
Table 2. Among both university and vocational college graduates, the skills gap is largest in programming (continued)

\begin{tabular}{|c|c|c|c|}
\hline \multicolumn{4}{|c|}{ B. Percentage of vocational college graduates reporting shortage of skills, 2013} \\
\hline Skill & Shortage & Adequate & Surplus \\
\hline Reading Comprehension & 40 & 48 & 12 \\
\hline Active Listening & 46 & 43 & 11 \\
\hline Writing & 41 & 49 & 10 \\
\hline Speaking & 52 & 38 & 10 \\
\hline Mathematics & 36 & 48 & 16 \\
\hline Science & 49 & 44 & 7 \\
\hline Critical Thinking & 42 & 51 & 7 \\
\hline Active Learning & 51 & 37 & 12 \\
\hline Learning Strategies & 47 & 43 & 10 \\
\hline Monitoring & 40 & 50 & 10 \\
\hline Social Perceptiveness & 46 & 44 & 10 \\
\hline Coordination & 45 & 44 & 11 \\
\hline Persuasion & 61 & 33 & 6 \\
\hline Negotiation & 53 & 37 & 10 \\
\hline Instructing & 41 & 45 & 14 \\
\hline Service Orientation & 48 & 42 & 10 \\
\hline Complex Problem Solving & 46 & 44 & 10 \\
\hline Operations Analysis & 50 & 42 & 8 \\
\hline Technology Design & 57 & 37 & 6 \\
\hline Equipment Selection & 38 & 55 & 7 \\
\hline Installation & 47 & 43 & 10 \\
\hline Programming & 78 & 15 & 7 \\
\hline Quality Control Analysis & 50 & 40 & 10 \\
\hline Operation Monitoring & 55 & 37 & 8 \\
\hline Operation and Control & 52 & 40 & 8 \\
\hline Equipment Maintenance & 55 & 38 & 7 \\
\hline Troubleshooting & 51 & 41 & 8 \\
\hline Repairing & 54 & 38 & 8 \\
\hline Systems Analysis & 54 & 37 & 9 \\
\hline Systems Evaluation & 33 & 58 & 9 \\
\hline Judgment and Decision Making & 50 & 40 & 10 \\
\hline Time Management & 40 & 45 & 15 \\
\hline Management of Financial Resources & 46 & 42 & 12 \\
\hline Management of Material Resources & 46 & 40 & 14 \\
\hline Management of Personnel Resources & 59 & 33 & 8 \\
\hline
\end{tabular}

Note: Vocational college graduates who had a job six months after graduation were asked whether the 5 skill categories out of 35 that are related to their job are necessary to perform their job (scale 1-7) and whether they had acquired the given skill by the time of graduation (scale 1-7). The difference between the weighted averages of the extent of necessity and the extent of acquired skills at school captures the skills gap or surplus. When the weighted averages of necessary and acquired skills are equal, skills are considered adequate.

Source: Authors' analyses based on MyCOS survey data.

\section{Gauging the knowledge gap}

10. In addition to skills, graduates were also asked about the knowledge they acquired or consider necessary for their jobs. Similarly to the skills mismatch, the knowledge gap is defined as the difference between knowledge demanded by employers and available in the market (i.e. acquired by students by the time they graduated).

11. There also appears to be a gap between the knowledge students acquire at higher education institutions and what is needed in their jobs. College training needs to catch up with the rapid development of services in recent years to provide enough professionals in areas such as sales and marketing, reported to have the greatest shortage: $64 \%$ of university and 59\% of vocational college graduates judge their 
knowledge in this area insufficient to perform their job (Figure 2 and Tables 3 and 4). Other services for which training is insufficient include personnel and human resources, therapy and counselling customers and personal services. The knowledge gap appears to be larger across all dimensions for university graduates compared to vocational college graduates. This likely reflects higher expectations and more complex tasks for university graduates rather than better preparedness of vocational college graduates.

Figure 2. Service-related training is not meeting labour market needs

Percentage of graduates reporting shortage of knowledge, top ten areas, 2013

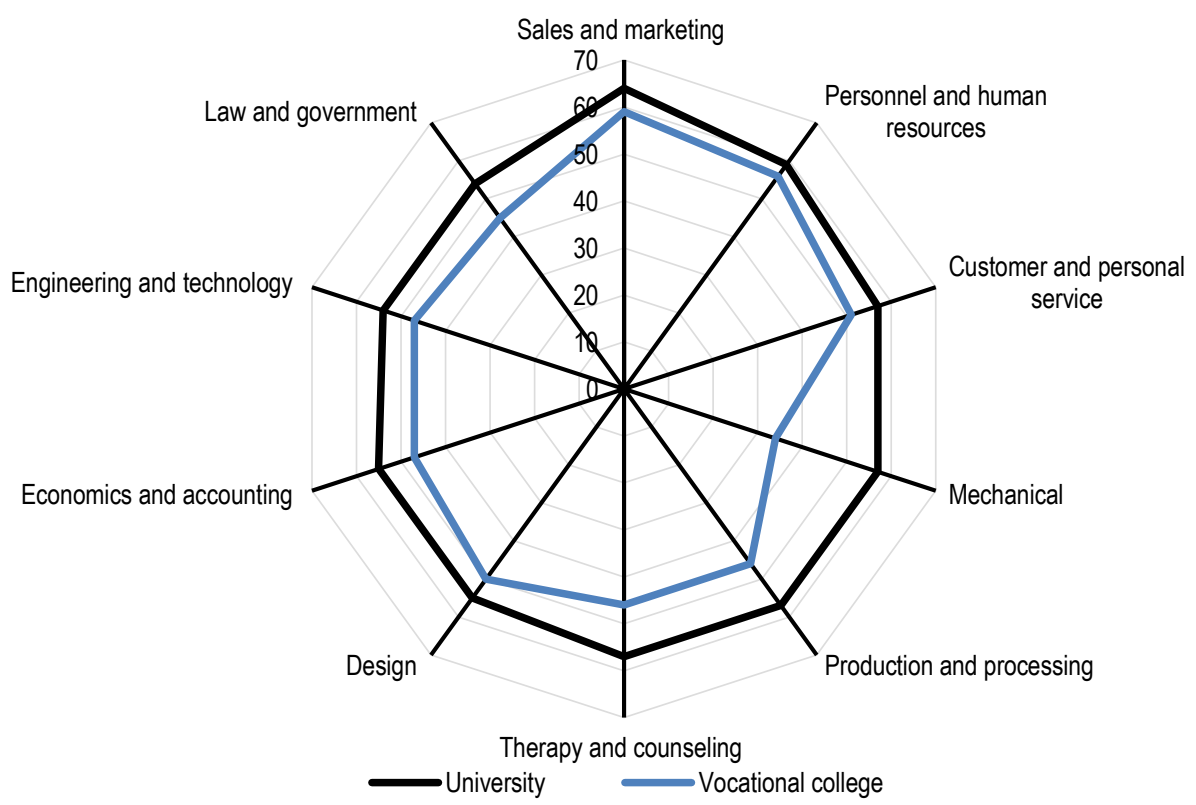

Note: University and vocational college graduates that had a job six months after graduation were asked whether the 5 knowledge categories out of 28 that are related to their job are necessary to perform their job (scale 1-7) and whether they had acquired the given knowledge by the time of graduation (scale 1-7). The difference between the weighted averages of the extent of necessity and the extent of acquired knowledge at school captures the knowledge gap. The ranking is based on the results for university graduates. Vocational college graduate knowledge shortages in the same knowledge categories are shown for comparison.

Source: Authors' analyses based on MyCOS survey data. 
Table 3. Among university graduates, the knowledge gap is largest in sales and marketing, HR and services

Percentage of university graduates 6 months after graduation, 2013

\begin{tabular}{|c|c|c|c|}
\hline Knowledge area & Shortage & Adequate & Surplus \\
\hline $\begin{array}{l}\text { Administration and Management } \\
\text { Biology } \\
\text { Chemistry } \\
\text { Clerical } \\
\text { Communications and Media } \\
\text { Computers and Electronics } \\
\text { Customer and Personal Service } \\
\text { Design } \\
\text { Economics and Accounting } \\
\text { Education and Training } \\
\text { Engineering and Technology } \\
\text { English Language } \\
\text { Fine Arts } \\
\text { Foreign Language } \\
\text { Geography } \\
\text { History and Archaeology } \\
\text { Law and Government } \\
\text { Mathematics } \\
\text { Mechanical } \\
\text { Personnel and Human Resources } \\
\text { Philosophy } \\
\text { Physics } \\
\text { Production and Processing } \\
\text { Psychology } \\
\text { Sales and Marketing } \\
\text { Sociology and Anthropology } \\
\text { Telecommunications } \\
\text { Therapy and Counselling }\end{array}$ & $\begin{array}{l}52 \\
44 \\
49 \\
44 \\
41 \\
44 \\
57 \\
55 \\
55 \\
53 \\
54 \\
34 \\
51 \\
46 \\
40 \\
49 \\
54 \\
35 \\
57 \\
59 \\
33 \\
41 \\
57 \\
52 \\
64 \\
40 \\
47 \\
57\end{array}$ & $\begin{array}{l}40 \\
48 \\
39 \\
46 \\
49 \\
47 \\
36 \\
37 \\
36 \\
39 \\
39 \\
49 \\
40 \\
41 \\
48 \\
39 \\
40 \\
48 \\
36 \\
33 \\
57 \\
45 \\
36 \\
40 \\
29 \\
49 \\
44 \\
39\end{array}$ & $\begin{array}{r}8 \\
8 \\
12 \\
10 \\
10 \\
9 \\
7 \\
8 \\
9 \\
8 \\
7 \\
17 \\
9 \\
13 \\
12 \\
12 \\
6 \\
17 \\
7 \\
8 \\
10 \\
14 \\
7 \\
8 \\
7 \\
11 \\
9 \\
4\end{array}$ \\
\hline
\end{tabular}

Note: University graduates that had a job six months after graduation were asked whether the 5 knowledge categories out of 28 that are related to their job are necessary to perform their job (scale 1-7) and whether they had acquired the given knowledge by the time of graduation (scale 1-7). The difference between the weighted averages of the extent of necessity and the extent of acquired knowledge at school captures the knowledge gap or surplus. When the weighted averages of necessary and acquired knowledge are equal, knowledge is considered adequate.

Source: Authors' analyses based on MyCOS survey data. 
ECO/WKP(2015)38

Table 4. The knowledge gap is greatest in among vocational college graduates

Percentage of vocational college graduates six months after graduation, 2013

\begin{tabular}{|c|c|c|c|}
\hline Knowledge area & Shortage & Adequate & Surplus \\
\hline $\begin{array}{l}\text { Administration and Management } \\
\text { Biology } \\
\text { Chemistry } \\
\text { Clerical } \\
\text { Communications and Media } \\
\text { Computers and Electronics } \\
\text { Customer and Personal Service } \\
\text { Design } \\
\text { Economics and Accounting } \\
\text { Education and Training } \\
\text { Engineering and Technology } \\
\text { English Language } \\
\text { Fine Arts } \\
\text { Foreign Language } \\
\text { Geography } \\
\text { History and Archaeology } \\
\text { Law and Government } \\
\text { Mathematics } \\
\text { Mechanical } \\
\text { Personnel and Human Resources } \\
\text { Physics } \\
\text { Production and Processing } \\
\text { Psychology } \\
\text { Sales and Marketing } \\
\text { Sociology and Anthropology } \\
\text { Telecommunications } \\
\text { Therapy and Counselling }\end{array}$ & $\begin{array}{l}49 \\
41 \\
44 \\
46 \\
40 \\
38 \\
51 \\
50 \\
47 \\
48 \\
47 \\
36 \\
53 \\
44 \\
32 \\
51 \\
45 \\
34 \\
34 \\
56 \\
39 \\
46 \\
52 \\
59 \\
44 \\
36 \\
46\end{array}$ & $\begin{array}{l}44 \\
51 \\
48 \\
46 \\
51 \\
53 \\
42 \\
43 \\
45 \\
45 \\
46 \\
53 \\
41 \\
49 \\
58 \\
40 \\
49 \\
55 \\
55 \\
38 \\
52 \\
45 \\
42 \\
35 \\
47 \\
54 \\
46\end{array}$ & $\begin{array}{r}7 \\
8 \\
8 \\
8 \\
9 \\
9 \\
7 \\
7 \\
8 \\
7 \\
7 \\
11 \\
6 \\
7 \\
10 \\
9 \\
6 \\
11 \\
11 \\
6 \\
9 \\
9 \\
6 \\
6 \\
9 \\
10 \\
8\end{array}$ \\
\hline
\end{tabular}

Source: Authors' analyses based on MyCOS survey data.

\section{Getting employed}

12. Notwithstanding skills and knowledge mismatches, roughly $82 \%$ of the 2013 graduates in the MyCOS survey data took up a full- or part-time position within six months following their graduation. A further $2 \%$ started their own business, $9 \%$ continued their studies and the remaining $8 \%$ were unemployed. The latter group includes graduates who continue their job search and discouraged applicants who gave up job hunting. Vocational college graduates display higher employment rates, higher entrepreneurship rates and higher unemployment rates than university graduates, but fewer of them continue their studies. More top university than other graduates tend to study further and not many give up their job search within half a year following graduation, though few have an entrepreneurial spirit.

13. Although internationally comparable data are not readily available, the share of graduates taking up a position among the ones wishing to take up one in China at $92 \%$ looks relatively high. It is only slightly lower than Japan's 95\%, though the Japanese graduate survey (Ministry of Health, Labour and Welfare, 2014) was conducted one year after graduation in contrast to the MyCOS survey six months after. Furthermore, also in Japan vocational college graduates display higher employment rates than university graduates. 
14. University graduates are more successful at securing prestigious jobs such as positions in government (16\% of them versus $7 \%$ of vocational college graduates), at state-owned enterprises (26\% versus $19 \%$ of vocational college graduates) and at foreign-invested firms (12\% versus $10 \%$ of vocational college graduates), while most vocational college graduates find employment in the private sector (63\% versus $45 \%$ of university graduates).

15. There are obviously large differences in the type of employment by major. Among the nine broad university major groups of agriculture, literature, management, science, engineering, economics, law, education and medicine, the medical profession is most government-oriented, while agriculture, for instance, offers mainly private sector jobs. $42 \%$ of university graduates majoring in economics find jobs in the private sector, $32 \%$ in SOEs, $14 \%$ in foreign-invested enterprises and $11 \%$ in government agencies. No other major has a higher share employed by foreign-invested companies and only the share of engineering graduates going to SOEs is higher than that of economists.

16. Among vocational college graduates, from the 12 major groups (arts/design/media, construction, finance/economics, light and food industry, electronics and IT, tourism, culture and education, manufacturing, chemicals and medicine, raw materials and energy, transportation and health) health professionals have the greatest chance to get a government job, followed by the culture and education major.

17. Although the overall unemployment rate of fresh graduates is relatively low at around $8 \%$ six months after graduation, it varies by major. Among university graduates, natural science majors such as physics, biology, biotechnology and chemistry as well as law and music are less conducive to employment. Arts and design, legal affairs, investment and wealth management and language education are the vocational college majors with fewer chances to find employment.

\section{Mismatches cause a sizeable share of graduates to take up jobs unrelated to their studies}

18. Graduates very often end up in professions unrelated to their major (31\% of university and 38\% of vocational college graduates) partly because there are not sufficient openings related to their major (16\% of university and $12 \%$ of vocational college graduates who start a profession different from their major) (Table 5) or because they cannot reach the requirement for jobs related to their majors (11\% of university and $13 \%$ of vocational college graduates who take up positions unrelated to what they studied) (Table 6). This indicates that higher education institutions lag behind market demand: on the one hand they continue to train people in subject areas where market demand is limited and on the other hand they do not fully equip their students with the skills required for positions related to their studies. 
ECO/WKP(2015)38

Table 5. Many graduates fail to meet the requirements for jobs related to their majors

Percentage of graduates by main reason for taking up a job unrelated to their major, six months after graduation

\begin{tabular}{|c|c|c|c|}
\hline & $\begin{array}{c}2011 \\
\text { graduates }\end{array}$ & $\begin{array}{c}2012 \\
\text { graduates }\end{array}$ & $\begin{array}{c}2013 \\
\text { graduates }\end{array}$ \\
\hline \multicolumn{4}{|l|}{ A. University graduates } \\
\hline The job related to major does not meet my career expectation. & 42 & 43 & 33 \\
\hline Because of living pressure, have to find a job, then think about career. & - & - & 25 \\
\hline There are few jobs related to major. & 27 & 24 & 16 \\
\hline Cannot reach the requirement of the job related to major. & 15 & 14 & 11 \\
\hline Job which is not related to my major pays better. & 10 & 12 & 9 \\
\hline The working environment of the job related to my major is bad. & 6 & 7 & 6 \\
\hline \multicolumn{4}{|l|}{ B. Vocational college graduates } \\
\hline The job related to major does not meet my career expectation. & 39 & 38 & 29 \\
\hline Because of living pressure, have to find a job, then think about career. & - & - & 29 \\
\hline Cannot reach the requirement of the job related to major. & 25 & 19 & 13 \\
\hline There are few jobs related to major. & 19 & 19 & 12 \\
\hline Job which is not related to my major pays better. & 10 & 14 & 10 \\
\hline The working environment of the job related to my major is bad. & 7 & 10 & 7 \\
\hline
\end{tabular}

Note: Sample size for university graduates is 29000 , for vocational college graduates 14000 .

Source: Authors' analyses based on MyCOS survey data.

Table 6. Unfulfilled career hopes are the main reason for dissatisfaction with jobs among university graduates

Percentage of university graduates by job expectation mismatch, six months after graduation

\begin{tabular}{l|c|c|c}
\hline University & $\mathbf{2 0 1 1}$ graduates & $\mathbf{2 0 1 2}$ graduates & 2013 graduates \\
\hline Match & 43.9 & 47.2 & 46.4 \\
Mismatch & 56.1 & 52.8 & 53.6 \\
Reason for mismatch: & 35.9 & 34.8 & 33.3 \\
It does not match my career development plan & 21.9 & 21.6 & 24.1 \\
It does not match my interests & 14.4 & 16.0 & 14.8 \\
It does not match my life style & 12.0 & 11.2 & 9.3 \\
It does not match my character & 15.8 & 16.4 & 18.5 \\
It does not match for other reasons & & &
\end{tabular}

Source: Authors' analyses based on MyCOS survey data.

19. The main reason for taking up a job unrelated to one's major is the career expectation gap (33\% of university graduates who took up unrelated jobs in 2013). The soaring number of university graduates has fuelled expectations of a well-respected white-collar job. More rigorous career guidance could reduce expectation gaps. One quarter of the university graduates and an even larger share of vocational college graduates cannot afford waiting for the right match and therefore take up positions that are unrelated to what they studied.

20. Furthermore, more than half of university graduates find that their job does not meet their expectations, mainly due to disappointing progression prospects (Table 7). Another quarter say their job does not match their interests. The share of vocational graduates who find that their jobs do not meet expectations is even higher (60\%) (Table 8). On average, two-thirds of the graduates who are not satisfied with their job are dissatisfied with their pay, regardless of whether they graduated from a university or a vocational college. The corresponding share among top (211 Project) university graduates is somewhat lower at $62 \%$. 
Table 7. A large share of vocational college graduates find their jobs far from what they expected Percentage of vocational college graduates by job expectation mismatch, six months after graduation

\begin{tabular}{l|c|c|c}
\hline Vocational college & $\mathbf{2 0 1 1}$ graduates & $\mathbf{2 0 1 2}$ graduates & $\mathbf{2 0 1 3}$ graduates \\
\hline Match & 40.3 & 40.4 & 40.4 \\
Mismatch & 59.7 & 59.6 & 59.6 \\
Reason for mismatch: & 38.5 & 35.7 & 33.3 \\
It does not match my career development plan & 21.2 & 20.9 & 21.7 \\
It does not match my interests & 13.3 & 16.4 & 13.3 \\
It does not match my life style & 9.0 & 8.8 & 11.7 \\
It does not match my character & 18.0 & 18.2 & 20.0 \\
It does not match, for other reasons & & & \\
\hline Source: Authors' analyses based on MyCOS survey data.
\end{tabular}

21. Gaps between proficiencies required for a job and acquired by applicants along with slower than expected career progression can lead to dissatisfaction and quits. Overall 34\% of graduates quit their jobs within half a year following graduation. This masks considerable differences across types of tertiary institutions: for 211 Project university graduates, this share stands at $13 \%$, while for vocational college graduates it reaches $43 \%$; for ordinary universities it is $26 \%$. These ratios have been stable in the past few years.

Table 8. Quit rates are high among vocational college graduates

Ratio of employees quitting within six months after graduation, 2012 and 2013 graduates

\begin{tabular}{lcc}
\hline & $\mathbf{2 0 1 2}$ graduates & 2013 graduates \\
\cline { 2 - 3 } 211 university graduates & 13 & 13 \\
Non-211 university graduates & 26 & 26 \\
Vocational college graduates & 42 & 43 \\
All graduates & 33 & 34 \\
\hline
\end{tabular}

Note: includes all graduates who quit regardless of the reason for quitting.

Source: Authors' analyses based on MyCOS survey data.

22. There are also differences across majors. Among university graduates, literature majors are most likely to quit within half a year (30\%), followed by economists $(28 \%)$. Engineers and medical personnel are less likely to do so (18\% for both). Vocational graduates majoring in health are also less likely to quit (21\%) compared to other majors. In contrast, around half of vocational college graduates majoring in arts/design/media, tourism and electronics and IT quit within half a year.

23. The major reason to quit is limited room for personal development (51\% of the cases), followed by low salary and benefits (49\%) and the wish to change profession or industry (35\%) (multiple choices were allowed from eight options: limited room for personal development, low salary and benefits, wish to change profession or industry, misfit with management system or corporate culture, high requirements and pressure, lack of job security, lack of guidance on direct responsibility and continuation of studies). Other reasons such as misfit with management system or corporate culture, high requirements and pressure and lack of job security are less important with $20 \%, 18 \%$ and $16 \%$ shares, respectively.

\section{Inequalities in education stem from various sources}

24. Individual opportunity is largely determined early in life: being born in a rural or an urban area and having the respective residence permit or hukou leaves a mark on one's career and life. Rural pupils have fewer opportunities to participate in pre-school education and have less access to good primary and middle schools. They are also less likely to pass the entrance exams of good urban high schools given that rural middle schools and urban migrant children's schools tend to be of lower quality. Moreover, they are 
less likely than their urban counterparts to have access to and ability to afford tutoring classes preparing students throughout their study life for the exams to enter higher institutions.

25. Children from an average family background face stiffer competition than those of various groups of privileged people (Zhan, 2012 and Zhang, 2013) who in Beijing for example make up nearly half of the new intakes at the middle-school level. Such privileges can stem from positions in the economy or society and children of these people are called tiaozisheng (pupil with a "note"). Others are admitted through "joint construction" agreements between government agencies or firms and schools to secure places for employees' children in exchange of contributing to school operation and construction (gongjiansheng). Moreover, students who do not meet the minimum credit required by a coveted school (but are close) can buy the missing credit through financial contributions to the school. Nevertheless, pupils with special skills can also enjoy preferential admission conditions.

26. The geographical area also matters for the chance to receive good education: although all cities have some good schools due to streaming policies, Beijing and other municipalities have the best ones at all levels. The distribution of universities, in particular of good ones, is uneven and some provinces lack top league universities altogether. Vocational colleges are more evenly distributed across the country.

27. Between-school differences matter greatly for careers. Tertiary educational institutions can be broadly classified into three groups: top (211 Project) universities, ordinary universities and vocational colleges. The latter group is the last resort for high school graduates not admitted to a university and until recently there had not been a chance to switch between school types.

\section{The family/social background matters for schooling, but once one receives tertiary education, less so for wages}

28. Most graduates come from peasant and peasant-worker families. The share of such graduates is higher in vocational colleges than in universities and higher in ordinary universities than top ones (Table 9). Those shares appear to be relatively stable over the past three years. Industry- and serviceworker children are also somewhat less represented among top university graduates than among ordinary university or vocational college graduates. In contrast, top universities have a higher share of graduates with parents having white-collar professional occupations.

Table 9. The social background matters for schooling

Percentage of tertiary graduates with various parental backgrounds

\begin{tabular}{|c|c|c|c|c|c|}
\hline College type & $\begin{array}{c}\text { Industry } \\
\text { and service } \\
\text { worker }\end{array}$ & Manager & $\begin{array}{c}\text { Peasant } \\
\text { and peasant- } \\
\text { worker }\end{array}$ & $\begin{array}{l}\text { Unemployed } \\
\text { and retired }\end{array}$ & $\begin{array}{l}\text { White-collar } \\
\text { professional }\end{array}$ \\
\hline $\begin{array}{l}2011 \text { graduates } \\
\text { Project } 211 \text { universities } \\
\text { Other universities } \\
\text { Vocational colleges }\end{array}$ & $\begin{array}{l}22 \\
24 \\
23 \\
\end{array}$ & $\begin{array}{l}15 \\
14 \\
12 \\
\end{array}$ & $\begin{array}{l}41 \\
42 \\
49 \\
\end{array}$ & $\begin{array}{l}7 \\
8 \\
7 \\
\end{array}$ & $\begin{array}{r}15 \\
12 \\
9 \\
\end{array}$ \\
\hline $\begin{array}{l}2012 \text { graduates } \\
\text { Project } 211 \text { universities } \\
\text { Other universities } \\
\text { Vocational colleges }\end{array}$ & $\begin{array}{l}22 \\
24 \\
23 \\
\end{array}$ & $\begin{array}{l}17 \\
15 \\
12 \\
\end{array}$ & $\begin{array}{l}39 \\
42 \\
50 \\
\end{array}$ & $\begin{array}{l}6 \\
7 \\
7 \\
\end{array}$ & $\begin{array}{r}16 \\
12 \\
8 \\
\end{array}$ \\
\hline $\begin{array}{l}2013 \text { graduates } \\
\text { Project } 211 \text { universities } \\
\text { Other universities } \\
\text { Vocational colleges }\end{array}$ & $\begin{array}{l}21 \\
23 \\
23\end{array}$ & $\begin{array}{l}16 \\
16 \\
11\end{array}$ & $\begin{array}{l}41 \\
42 \\
50\end{array}$ & $\begin{array}{l}5 \\
7 \\
8\end{array}$ & $\begin{array}{r}17 \\
12 \\
8\end{array}$ \\
\hline
\end{tabular}

Note: "211" universities represent around 100 top institutions to train talents for the 21st century and non-"211" universities are the remaining nearly 1000 institutions. Vocational colleges are tertiary vocational institutions.

Source: Authors' analyses based on MyCOS survey data. 
29. Most university graduates have parents with upper secondary education while most vocational college graduates have parents with lower secondary education (Table 10). Also, more vocational college than university graduates have parents with no higher than primary-level education. The contrast is sharpest for highly educated parents: the share of university graduates with parents of at least universitylevel education is double the share for vocational college graduates.

Table 10. Vocational college graduates tend to have parents with lower educational attainment

Percentage of graduates with parents at various educational attainments, in 2013

\begin{tabular}{l|c|c}
\hline Family education background (parents) & University graduates & Vocational college graduates \\
\hline Primary or lower & 8 & 12 \\
Lower secondary & 33 & 43 \\
Upper secondary & 38 & 35 \\
Undergraduate degree & 19 & 9 \\
Masters or higher graduate degrees & 2 & 1 \\
\hline
\end{tabular}

Note: The sample size is 43000 .

Source: Authors' analyses based on MyCOS survey data.

30. Moreover, when choosing among universities, children of university-educated parents are more likely to get into the top universities (Table 11). Also, more top university graduates have parents with graduate-level (Masters’ or higher) education.

Table 11. Children of university graduates are more likely to go to the top universities

Percentage of vocational college graduates

\begin{tabular}{|l|l|c|c|c|}
\hline & Family education background (parents) & $\begin{array}{c}\text { Project } \\
\text { 211 universities }\end{array}$ & $\begin{array}{c}\text { Other } \\
\text { universities }\end{array}$ & $\begin{array}{c}\text { Vocational } \\
\text { colleges }\end{array}$ \\
\hline \multirow{4}{*}{2011} & Primary or lower & 8 & 9 & 9 \\
graduates & Lower secondary & 29 & 31 & 40 \\
& Upper secondary & 40 & 43 & 40 \\
& Undergraduate degree & 21 & 16 & 10 \\
& Masters or higher graduate degrees & 2 & 1 & 1 \\
\hline \multirow{5}{*}{2012} & Primary or lower & 8 & 9 & 9 \\
graduates & Lower secondary & 29 & 34 & 40 \\
& Upper secondary & 35 & 39 & 39 \\
& Undergraduate degree & 25 & 17 & 11 \\
2013 & Masters or higher graduate degrees & 3 & 1 & 1 \\
\hline \multirow{5}{*}{ graduates } & Primary or lower & 8 & 8 & 12 \\
& Lower secondary & 29 & 34 & 43 \\
& Upper secondary & 37 & 38 & 35 \\
& Undergraduate degree & 23 & 17 & 9 \\
\end{tabular}

Note: "211" universities represent around 100 top institutions to train talents for the 21 st century and non-"211" universities are the remaining nearly 1000 institutions. Vocational colleges are tertiary vocational institutions.

Source: Authors' analyses based on MyCOS survey data.

31. To assess the impact of social background in explaining wage variation, the Theil index measuring wage inequality across graduates (regardless of type of institution) was decomposed into a within and between family background component. Only $1.2 \%$ of wage variation is explained by the between-social-background variation. This indicates that once one overcomes the hurdle of getting tertiary education, the family background does not matter in determining wages, thus higher education is key to upward social mobility. 
32. The family background may not matter on average in explaining variation in wages as shown above by the decomposition of the wage variation into a within- and between-background component, but it is worth looking at how it might vary across brackets of the income distribution. Quantile regression techniques can be useful in this case insofar as the impact of the independent variables (here experience, firm size, parents' education and work city type, the latter two may be subject to multicollinearity) varies along the conditional distribution of the dependent variable (here wages). Therefore, in addition to pooled OLS estimates, quantile regression estimates are obtained to examine the impact of the above variables on wages (expressed in logarithmic form). The impact was estimated for all deciles and the results show that parents' education matters more at the upper end of the wage distribution. In the first estimation for university graduates, inequality increases with parents' education as increasing coefficients on the parents' education variable mean that the wage distribution spreads out as parents are more educated (Table 12). The same pattern cannot be observed for vocational college graduates: the coefficient on parents' education is only significant (and positive) in the two upper deciles. This, however, still indicates that in those deciles parents' education matters. The type of the city people work in matters more for the lower end of the wage distribution for both types of graduates. The coefficient is always significant and negative and, indicating that lower wages are a result of working in smaller cities or towns. The impact of firm size is always significant and positive: larger firms pay better. Experience appears to matter more for lowincome earners in the case of both types of graduates. 
ECO/WKP(2015)38

Table 12. Determinants of wages differ along the wage distribution and between university and vocational college graduates

Quantile regression estimates by wage decile and OLS estimates, 2011-13

\begin{tabular}{|c|c|c|c|c|c|c|c|c|c|c|c|}
\hline & \multirow[t]{2}{*}{$\begin{array}{c}\text { Number of } \\
\text { observations }\end{array}$} & \multicolumn{9}{|c|}{ Quantile regression estimates } & \multirow[t]{2}{*}{$\begin{array}{c}\text { OLS } \\
\text { estimates }\end{array}$} \\
\hline & & 0.1 & 0.2 & 0.3 & 0.4 & 0.5 & 0.6 & 0.7 & 0.8 & 0.9 & \\
\hline University graduates & 34735 & & & & & & & & & & \\
\hline Experience & & $\begin{array}{l}0.064^{\star \star \star} \\
(0.005)\end{array}$ & $\begin{array}{l}0.064^{\star \star \star} \\
(0.004)\end{array}$ & $\begin{array}{l}0.064^{\star \star \star} \\
(0.003)\end{array}$ & $\begin{array}{l}0.064^{\star \star \star} \\
(0.003)\end{array}$ & $\begin{array}{l}0.062^{\star \star \star} \\
(0.004)\end{array}$ & $\begin{array}{l}0.056^{\star \star *} \\
(0.002)\end{array}$ & $\begin{array}{l}0.054^{\star \star \star} \\
(0.005)\end{array}$ & $\begin{array}{l}0.055^{\star \star \star} \\
(0.006)\end{array}$ & $\begin{array}{l}0.053^{\star \star \star} \\
(0.006)\end{array}$ & $\begin{array}{l}0.059^{\star \star *} \\
(0.003)\end{array}$ \\
\hline Experience square & & $\begin{array}{l}-0.003^{* \star *} \\
(0.000)\end{array}$ & $\begin{array}{l}-0.003^{\star * *} \\
(0.000)\end{array}$ & $\begin{array}{l}-0.003^{* * *} \\
(0.000)\end{array}$ & $\begin{array}{l}-0.003^{* \star *} \\
(0.000)\end{array}$ & $\begin{array}{l}-0.003^{\star * *} \\
(0.000)\end{array}$ & $\begin{array}{l}-0.003^{\star * \star} \\
(0.000)\end{array}$ & $\begin{array}{l}-0.003^{* \star *} \\
(0.000)\end{array}$ & $\begin{array}{l}-0.003^{* \star *} \\
(0.000)\end{array}$ & $\begin{array}{l}-0.003^{\star * *} \\
(0.000)\end{array}$ & $\begin{array}{l}-0.003^{\star * \star} \\
(0.000)\end{array}$ \\
\hline Firm size & & $\begin{array}{l}0.049^{\star * \star} \\
(0.002)\end{array}$ & $\begin{array}{l}0.047^{* * *} \\
(0.002)\end{array}$ & $\begin{array}{l}0.048^{* * *} \\
(0.001)\end{array}$ & $\begin{array}{l}0.043^{* * *} \\
(0.001)\end{array}$ & $\begin{array}{l}0.043^{\star \star *} \\
(0.001)\end{array}$ & $\begin{array}{l}0.044^{* * *} \\
(0.001)\end{array}$ & $\begin{array}{l}0.046^{\star * *} \\
(0.002)\end{array}$ & $\begin{array}{l}0.049^{* * *} \\
(0.002)\end{array}$ & $\begin{array}{l}0.048^{* * *} \\
(0.002)\end{array}$ & $\begin{array}{l}0.046^{* * *} \\
(0.001)\end{array}$ \\
\hline Parents' education & & $\begin{array}{l}0.007^{\star \star} \\
(0.003)\end{array}$ & $\begin{array}{l}0.014^{* * *} \\
(0.003)\end{array}$ & $\begin{array}{l}0.018^{* * *} \\
(0.002)\end{array}$ & $\begin{array}{l}0.018^{* * *} \\
(0.002)\end{array}$ & $\begin{array}{l}0.022^{* * *} \\
(0.003)\end{array}$ & $\begin{array}{l}0.023^{* * *} \\
(0.001)\end{array}$ & $\begin{array}{l}0.027^{\star * *} \\
(0.003)\end{array}$ & $\begin{array}{l}0.028^{* * *} \\
(0.004)\end{array}$ & $\begin{array}{l}0.040^{* * *} \\
(0.002)\end{array}$ & $\begin{array}{l}0.022^{* * *} \\
(0.002)\end{array}$ \\
\hline Work city type & & $\begin{array}{l}-0.133^{* \star *} \\
(0.004)\end{array}$ & $\begin{array}{l}-0.136^{\star \star *} \\
(0.003)\end{array}$ & $\begin{array}{l}-0.130^{\star \star \star} \\
(0.002)\end{array}$ & $\begin{array}{l}-0.132^{\star \star *} \\
(0.002)\end{array}$ & $\begin{array}{l}-0.127^{* * \star} \\
(0.003)\end{array}$ & $\begin{array}{l}-0.133^{\star \star \star} \\
(0.001)\end{array}$ & $\begin{array}{l}-0.132^{\star * *} \\
(0.003)\end{array}$ & $\begin{array}{l}-0.132^{* * *} \\
(0.004)\end{array}$ & $\begin{array}{l}-0.120^{* \star *} \\
(0.004)\end{array}$ & $\begin{array}{l}-0.130^{* * *} \\
(0.002)\end{array}$ \\
\hline Trend & & $\begin{array}{l}0.091^{\star * \star} \\
(0.003)\end{array}$ & $\begin{array}{l}0.086^{\star \star *} \\
(0.002)\end{array}$ & $\begin{array}{l}0.089^{* \star \star} \\
(0.002)\end{array}$ & $\begin{array}{l}0.085^{\star \star \star} \\
(0.002)\end{array}$ & $\begin{array}{l}0.084^{\star \star \star} \\
(0.003)\end{array}$ & $\begin{array}{l}0.078^{\star \star \star} \\
(0.001)\end{array}$ & $\begin{array}{l}0.073^{\star \star \star} \\
(0.003)\end{array}$ & $\begin{array}{l}0.075^{\star \star \star} \\
(0.004)\end{array}$ & $\begin{array}{l}0.067^{\star \star \star} \\
(0.004)\end{array}$ & $\begin{array}{l}0.079^{\star * \star} \\
(0.002)\end{array}$ \\
\hline Constant & & $\begin{array}{l}7.239^{\star \star *} \\
(0.024)\end{array}$ & $\begin{array}{l}7.400^{\star * *} \\
(0.019)\end{array}$ & $\begin{array}{l}7.473^{\star * *} \\
(0.016)\end{array}$ & $\begin{array}{l}7.604^{\star * *} \\
(0.015)\end{array}$ & $\begin{array}{l}7.675^{\star * *} \\
(0.020)\end{array}$ & $\begin{array}{l}7.802^{* * *} \\
(0.007)\end{array}$ & $\begin{array}{l}7.890^{\star \star \star \star} \\
(0.022)\end{array}$ & $\begin{array}{l}7.980^{\star \star \star *} \\
(0.028)\end{array}$ & $\begin{array}{l}8.136^{* \star *} \\
(0.029)\end{array}$ & $\begin{array}{l}7.692^{* * *} \\
(0.015)\end{array}$ \\
\hline Vocational college graduates & 13036 & & & & & & & & & & \\
\hline Experience & & $\begin{array}{l}0.029^{\star \star \star} \\
(0.009)\end{array}$ & $\begin{array}{l}0.035^{\star \star \star} \\
(0.007)\end{array}$ & $\begin{array}{l}0.032^{\star * \star} \\
(0.005)\end{array}$ & $\begin{array}{l}0.023^{\star \star \star} \\
(0.007)\end{array}$ & $\begin{array}{c}0.030^{\star * \star} \\
(0.001)\end{array}$ & $\begin{array}{l}0.020^{\star * *} \\
(0.006)\end{array}$ & $\begin{array}{l}0.016^{* \star \star} \\
(0.007)\end{array}$ & $\begin{array}{l}0.013^{\star \star *} \\
(0.006)\end{array}$ & $\begin{array}{l}0.019^{* * *} \\
(0.010)\end{array}$ & $\begin{array}{l}0.025^{\star \star \star} \\
(0.005)\end{array}$ \\
\hline Experience square & & $\begin{array}{l}-0.000 \\
(0.001)\end{array}$ & $\begin{array}{l}-0.001^{* * *} \\
(0.000)\end{array}$ & $\begin{array}{l}-0.001^{* * *} \\
(0.000)\end{array}$ & $\begin{array}{l}-0.001 \\
(0.000)\end{array}$ & $\begin{array}{l}-0.001^{* * *} \\
(0.000)\end{array}$ & $\begin{array}{l}-0.001^{*} \\
(0.000)\end{array}$ & $\begin{array}{l}-0.001 \\
(0.000)\end{array}$ & $\begin{array}{l}-0.000 \\
(0.000)\end{array}$ & $\begin{array}{l}-0.000 \\
(0.000)\end{array}$ & $\begin{array}{l}-0.000^{* *} \\
(0.000)\end{array}$ \\
\hline Parents' education & & $\begin{array}{l}-0.016^{* *} \\
(0.006)\end{array}$ & $\begin{array}{l}-0.010 \\
(0.005)\end{array}$ & $\begin{array}{l}-0.005 \\
(0.003)\end{array}$ & $\begin{array}{l}-0.000 \\
(0.005)\end{array}$ & $\begin{array}{c}0.000 \\
(0.001)\end{array}$ & $\begin{array}{c}0.003 \\
(0.004)\end{array}$ & $\begin{array}{c}0.009 \\
(0.005)\end{array}$ & $\begin{array}{l}0.013^{\star * *} \\
(0.004)\end{array}$ & $\begin{array}{l}0.022^{* * *} \\
(0.008)\end{array}$ & $\begin{array}{c}0.001 \\
(0.004)\end{array}$ \\
\hline Work city type & & $\begin{array}{l}-0.107^{\star * *} \\
(0.007)\end{array}$ & $\begin{array}{l}-0.091^{* * *} \\
(0.005)\end{array}$ & $\begin{array}{l}-0.106^{\star * *} \\
(0.004)\end{array}$ & $\begin{array}{l}-0.104^{\star * *} \\
(0.006)\end{array}$ & $\begin{array}{l}-0.091^{\star * *} \\
(0.001)\end{array}$ & $\begin{array}{l}-0.084^{\star \star *} \\
(0.005)\end{array}$ & $\begin{array}{l}-0.078^{* * *} \\
(0.006)\end{array}$ & $\begin{array}{l}-0.091^{* * *} \\
(0.005)\end{array}$ & $\begin{array}{l}-0.075^{\star * *} \\
(0.008)\end{array}$ & $\begin{array}{l}-0.093^{* \star *} \\
(0.004)\end{array}$ \\
\hline Trend & & $\begin{array}{l}0.077^{* * *} \\
(0.008)\end{array}$ & $\begin{array}{l}0.077^{\star * *} \\
(0.007)\end{array}$ & $\begin{array}{l}0.078^{\star * *} \\
(0.005)\end{array}$ & $\begin{array}{l}0.088^{* * *} \\
(0.007)\end{array}$ & $\begin{array}{l}0.102^{\star * *} \\
(0.001)\end{array}$ & $\begin{array}{l}0.086^{* * *} \\
(0.006)\end{array}$ & $\begin{array}{l}0.081^{\star \star *} \\
(0.007)\end{array}$ & $\begin{array}{l}0.082^{* * *} \\
(0.006)\end{array}$ & $\begin{array}{l}0.099^{* * *} \\
(0.001)\end{array}$ & $\begin{array}{l}0.082^{* \star *} \\
(0.005)\end{array}$ \\
\hline Constant & & $\begin{array}{l}7.244^{* * *} \\
(0.045)\end{array}$ & $\begin{array}{l}7.344^{* * *} \\
(0.036)\end{array}$ & $\begin{array}{l}7.481^{* * *} \\
(0.025)\end{array}$ & $\begin{array}{l}7.543^{* * *} \\
(0.038)\end{array}$ & $\begin{array}{l}7.584^{* * *} \\
(0.007)\end{array}$ & $\begin{array}{l}7.720^{* * *} \\
(0.032)\end{array}$ & $\begin{array}{l}7.809^{\star * *} \\
(0.039)\end{array}$ & $\begin{array}{l}7.895^{\star * *} \\
(0.034)\end{array}$ & $\begin{array}{l}7.974^{* * *} \\
(0.055)\end{array}$ & $\begin{array}{l}7.626^{\star * \star} \\
(0.028)\end{array}$ \\
\hline
\end{tabular}

Note: in denotes significance at the $1 \%$, at the $5 \%$ and " at the $10 \%$ level. Standard errors are in parentheses. The dependent variable is monthly wages measured in thousands CNY, in logarithmic form. Independent variables are experience measured in months (it can be higher than six as some students have started working before they graduated), firm size (six size categories measured by the number of employees are assigned values from 1 to 6 from the size category below-50 workers to above 3000 workers), parents' education (five educational attainment categories are assigned values from 1 to 5 , starting with primary or lower education all the way to graduate education) and work city type (taking three values, 1 for municipalities, 2 for sub-provincial cities and 3 for prefecture-level cities and below).

Source: Authors' analyses based on MyCOS survey data. 


\section{Bigger cities offer significantly higher wages}

33. Both average and median wages in the four municipalities of Beijing, Chongqing, Shanghai and Tianjin are much higher than in the next group of 15 cities or the remaining cities and rural areas, though living costs are also much higher (Table 13). The difference between wages in the four megacities and small cities and rural areas ranges between $20-30 \%$. Not only initial wages are higher, but earning prospects are brighter in megacities than in other areas (Table 14).

Table 13. The four municipalities offer $20-30 \%$ higher wages than small cities or rural areas Monthly wages in CNY six months after graduation

\begin{tabular}{l|l|c|c|c|c|cc|c}
\hline \multirow{2}{*}{$\begin{array}{c}\text { Education } \\
\text { background }\end{array}$} & \multicolumn{1}{|c|}{ City level } & \multicolumn{3}{c|}{ Mean } & \multicolumn{3}{c}{ Median } \\
\cline { 3 - 8 } & & $\begin{array}{c}2011 \\
\text { graduates }\end{array}$ & $\begin{array}{c}2012 \\
\text { graduates }\end{array}$ & $\begin{array}{c}2013 \\
\text { graduates }\end{array}$ & $\begin{array}{c}2011 \\
\text { graduates }\end{array}$ & $\begin{array}{c}2012 \\
\text { graduates }\end{array}$ & $\begin{array}{c}2013 \\
\text { graduates }\end{array}$ \\
\hline $\begin{array}{l}\text { University } \\
\text { University }\end{array}$ & Municipality & 3675 & 4101 & 4127 & 3349 & 3600 & 3700 \\
$\begin{array}{l}\text { Sub-provincial city } \\
\text { University }\end{array}$ & $\begin{array}{l}\text { Cities below prefectural } \\
\text { levels and rural areas }\end{array}$ & 2752 & 3020 & 3185 & 2500 & 2800 & 3000 \\
$\begin{array}{l}\text { Vocational } \\
\text { college }\end{array}$ & Municipality & 2903 & 3273 & 3366 & 2700 & 3000 & 3000 \\
$\begin{array}{l}\text { Vocational } \\
\text { college }\end{array}$ & Sub-provincial city & 2526 & 2779 & 3038 & 2400 & 2500 & 3000 \\
$\begin{array}{l}\text { Vocational } \\
\text { college }\end{array}$ & $\begin{array}{l}\text { Cities below prefectural } \\
\text { levels and rural areas }\end{array}$ & 2295 & 2575 & 2772 & 2000 & 2400 & 2500 \\
\hline
\end{tabular}

Note: Municipalities include Beijing, Chongqing, Shanghai and Tianjin. Sub-provincial cities comprise 15 cities: Harbin, Changchun, Shenyang, Dalian, Jinan, Qingdao, Nanjing, Hangzhou, Ningbo, Xiamen, Guangzhou, Shenzhen, Wuhan, Chengdu and Xian. Cities below prefectural levels include the remaining cities and rural areas. The sample size is 120000 . Graduates of the years of 2011, 2012 and 2013 were surveyed six months after their respective graduation. Answers about wages were rounded to the closest hundred.

Source: Authors' analyses based on MyCOS survey data.

Table 14. Earning prospects three years after graduation are brighter in megacities

Average and median monthly wages in CNY six months and three years after graduation, 2009 and 2010 graduates

\begin{tabular}{|c|c|c|c|c|c|c|c|c|c|}
\hline \multirow{3}{*}{$\begin{array}{c}\text { Education } \\
\text { back- } \\
\text { ground } \\
\end{array}$} & \multirow{3}{*}{ City level } & \multicolumn{4}{|c|}{ Mean } & \multicolumn{4}{|c|}{ Median } \\
\hline & & \multicolumn{2}{|c|}{2009 graduates } & \multicolumn{2}{|c|}{2010 graduates } & \multicolumn{2}{|c|}{2009 graduates } & \multicolumn{2}{|c|}{2010 graduates } \\
\hline & & $\begin{array}{c}3 \text { years } \\
\text { after } \\
\text { graduation }\end{array}$ & $\begin{array}{l}\text { Half-year } \\
\text { after } \\
\text { graduation }\end{array}$ & $\begin{array}{c}3 \text { years } \\
\text { after } \\
\text { graduation }\end{array}$ & $\begin{array}{c}\text { Half-year } \\
\text { after } \\
\text { graduation }\end{array}$ & $\begin{array}{c}3 \text { years } \\
\text { after } \\
\text { graduation }\end{array}$ & $\begin{array}{c}\text { Half-year } \\
\text { after } \\
\text { graduation }\end{array}$ & $\begin{array}{c}3 \text { years } \\
\text { after } \\
\text { graduation }\end{array}$ & $\begin{array}{l}\text { Half-year } \\
\text { after } \\
\text { graduation }\end{array}$ \\
\hline University & Municipality & 6590 & 2771 & 7343 & 3435 & 6000 & 2500 & 7000 & 3000 \\
\hline $\begin{array}{l}\text { University } \\
\text { University }\end{array}$ & $\begin{array}{l}\text { Sub- } \\
\text { provincial city } \\
\text { Cities below } \\
\text { prefectural } \\
\text { levels and } \\
\text { rural areas }\end{array}$ & 5667 & 2416 & 5170 & 3065 & 4000 & 2000 & 5000 & 2300 \\
\hline $\begin{array}{l}\text { Vocational } \\
\text { college }\end{array}$ & Municipality & 4728 & 2123 & 5505 & 2505 & 4000 & 2000 & 5000 & 2200 \\
\hline $\begin{array}{l}\text { Vocational } \\
\text { college } \\
\text { Vocational } \\
\text { college }\end{array}$ & $\begin{array}{l}\text { Sub- } \\
\text { provincial city } \\
\text { Cities below } \\
\text { prefectural } \\
\text { levels and } \\
\text { rural areas }\end{array}$ & 4330 & 1755 & 4908 & 2249 & 4000 & 1500 & 4500 & 1800 \\
\hline
\end{tabular}

Note: Municipalities include Beijing, Chongqing, Shanghai and Tianjin. Sub-provincial cities comprise 15 cities: Harbin, Changchun, Shenyang, Dalian, Jinan, Qingdao, Nanjing, Hangzhou, Ningbo, Xiamen, Guangzhou, Shenzhen, Wuhan, Chengdu and Xian. Cities below prefectural levels include the remaining cities and rural areas. The sample size is 30000.2009 and 2010 graduateswere surveyed three years after their respective graduation. Answers about wages were rounded to the closest hundred, therefore the medians are rounded, but the means were calculated from the answers and are thus non-rounded.

Source: Authors' analyses based on MyCOS survey data. 
34. Higher wages in bigger cities may be a reason for moving or for new graduates staying in the city where they studied. Nearly a third of university graduates take up a position in the city where they studied (Table 15). This share would seem to be low compared with, for instance, the United Kingdom, where over $60 \%$ of college graduates were employed in the region of their college six months after graduation (Ball, 2009). However, one reason for the apparent difference in mobility may be the spatial units across which mobility is examined (12 regions in the United Kingdom as against over 300 cities in China). In addition, daily commuting across regions is more common in the United Kingdom than it is across cities in China. The corresponding share for graduates of vocational colleges in China is seven percentage points higher at $38 \%$. This higher share may be related to the more widespread location of vocational colleges, including in county-level cities, while universities tend to be concentrated in megacities and in general located in prefecture-level cities and above. More university graduates take up a position in a megacity: $23 \%$ of them in contrast to $18 \%$ of vocational college graduates. Similarly more of them find jobs in sub-provincial cities, while vocational graduates' jobs are concentrated in prefecture-level cities or below (58\% vs. $46 \%$ for university graduates).

35. About half of the university graduates who take up a job in the city where they studied were also raised in that city. The corresponding share for vocational college graduates in China is only slightly lower. Again, these shares are much higher in the United Kingdom, subject to the same caveats.

Table 15. Many graduates take up a position in the city where they studied

Percentage of hired graduates working in the city where their college is located

\begin{tabular}{lccc}
\hline \multirow{2}{*}{ Education background } & \multicolumn{3}{c}{$\begin{array}{c}\text { Share of hired graduates working in the city } \\
\text { where their college is located }\end{array}$} \\
\cline { 2 - 4 } & 2011 graduates & 2012 graduates & 2013 graduates \\
\hline University & $29 \%$ & $32 \%$ & $31 \%$ \\
Vocational college & $39 \%$ & $37 \%$ & $38 \%$ \\
\hline
\end{tabular}

Note: Sample size is 146000 .

Source: Authors' analyses based on MyCOS survey data.

The size of the firm matters for wages

36. Mega-firms with 3000 employees and above on average pay a third more than small firms employing less than 50 people (Table 16). $27 \%$ of university graduates found a job in a mega-firm within six months after graduation in 2013, while the corresponding figure is $19 \%$ for vocational college graduates. Among university graduates, economists, engineers and management specialists have a greater chance to find such a job, while among vocational college graduates transportation, raw material and energy and manufacturing are the majors with a greater share of jobs in mega-firms. 
ECO/WKP(2015)38

Table 16. Mega-firms pay roughly a third more than small firms

Average monthly wages in CNY six months after graduation

\begin{tabular}{llccc}
\hline Education background & \multicolumn{1}{c}{ Firm staff size } & 2013 graduates & 2012 graduates & 2011 graduates \\
\hline University & above 3000 & 4021 & 3908 & 3547 \\
University & $1001-3000$ & 3742 & 3552 & 3283 \\
University & $501-1000$ & 3576 & 3362 & 3093 \\
University & $301-500$ & 3561 & 3272 & 3017 \\
University & $51-300$ & 3301 & 3094 & 2812 \\
University & 50 and below & 3096 & 2874 & 2602 \\
Vocational college & above 3000 & 3391 & 3214 & 2802 \\
Vocational college & $1001-3000$ & 3199 & 2939 & 2697 \\
Vocational college & $501-1000$ & 3065 & 2687 & 2592 \\
Vocational college & $301-500$ & 2986 & 2819 & 2523 \\
Vocational college & $51-300$ & 2856 & 2596 & 2385 \\
Vocational college & 50 and below & 2679 & 274 & 2279 \\
\hline
\end{tabular}

Note: Firm size is expressed in terms of the number of employees. The sample size is 127000.

Source: Authors' analyses based on MyCOS survey data.

\section{Education-related inequalities tend to be relatively small at the city and county levels}

37. As a complement to analyses using the individual-level MyCOS data, inequalities across cities and counties were measured using the Theil index for various education-related indicators. These indicators include spending, enrolment, distribution of schools and student-teacher ratios. Cities refer to prefecture-level cities, while counties do not include city districts at the county level. The advantage of the Theil index in measuring inequalities is that it can be decomposed into a within- and between-province component in the case of both the city-level and the county-level indices. This allows assessing whether inequalities stem from regional differences across provinces of different levels of development or from within-province differences that may be related to the urban-rural divide.

38. Per capita schools, teachers and enrolled students at tertiary level are unevenly distributed across cities, with Theil indices of $0.37,0.39$ and 0.41 , respectively (Table 17). Disparities mainly reflect withinprovince differences, which relates to the fact that tertiary education institutions, in particular universities, tend to be concentrated in the biggest cities, primarily in provincial capitals.

39. As a result of enhancing central government transfer spending on education, both outlays per capita and per student on education are relatively evenly distributed across cities. When decomposing such disparities, a slightly greater share is related to disparities between than within provinces, indicating varying levels of economic development and thus financing resources across provinces. Moreover, compared to secondary and higher education, the disparities in student-per-teacher ratios, student-perschool ratios and per capita number of enrolled students at the primary level across cities are somewhat larger, though still relatively small with Theil indices of $0.02,0.13$ and 0.04 , respectively. The betweenprovince component tends to be higher in two of these cases, suggesting that financing capacities of provinces may matter.

40. Disparities are not particularly high for student-per-teacher ratios at all levels and tend to reflect differences within more than between provinces; they are larger for primary than for secondary and higher education. Across either cities or counties, the distribution of the per capita number of enrolled students at primary and secondary schools is relatively even, and the inequality index value is larger for primary than secondary education (Tables 17 and 18). What is noteworthy is that disparities in the number of primaryschool students across counties appear to stem from within-province differences, while across cities from between-province differences. This may reflect the consequences of migration, i.e. from rural to urban areas as well as from less developed to more developed provinces. 
Table 17. Inequalities at the city level are relatively small in most education-related indicators

Theil indices of inequality

\begin{tabular}{|c|c|c|c|c|c|c|c|c|c|c|c|c|c|c|c|c|c|c|c|}
\hline Item & Year & $\begin{array}{c}\text { Govt } \\
\text { expenditure: } \\
\text { science } \\
\text { (per capita) }\end{array}$ & $\begin{array}{c}\text { Govt } \\
\text { expenditure: } \\
\text { education } \\
\text { (per capita) }\end{array}$ & $\begin{array}{l}\text { Ratio of govt } \\
\text { education } \\
\text { expenditure } \\
\text { to enrolled } \\
\text { students at } \\
\text { all levels }\end{array}$ & $\begin{array}{c}\text { No of } \\
\text { higher } \\
\text { institutions } \\
\text { (per capita) }\end{array}$ & $\begin{array}{l}\text { No of } \\
\text { secondary } \\
\text { schools } \\
\text { (per capita) }\end{array}$ & $\begin{array}{c}\text { No of } \\
\text { primary } \\
\text { schools } \\
\text { (per capita) }\end{array}$ & $\begin{array}{l}\text { No of } \\
\text { enrolled } \\
\text { students in } \\
\text { higher } \\
\text { institutions } \\
\text { (per capita) }\end{array}$ & $\begin{array}{l}\text { No of } \\
\text { enrolled } \\
\text { students in } \\
\text { secondary } \\
\text { schools } \\
\text { (per capita) }\end{array}$ & $\begin{array}{l}\text { No of } \\
\text { enrolled } \\
\text { students in } \\
\text { primary } \\
\text { schools } \\
\text { (per capita) }\end{array}$ & $\begin{array}{l}\text { No of full- } \\
\text { time } \\
\text { teachers: } \\
\text { higher } \\
\text { institutions } \\
\text { (per capita) }\end{array}$ & $\begin{array}{l}\text { No of full- } \\
\text { time } \\
\text { teachers: } \\
\text { secondary } \\
\text { schools } \\
\text { (per capita) }\end{array}$ & $\begin{array}{l}\text { No of full- } \\
\text { time } \\
\text { teachers: } \\
\text { primary } \\
\text { schools } \\
\text { (per capita) }\end{array}$ & $\begin{array}{l}\text { Ratio of } \\
\text { teachers to } \\
\text { students in } \\
\text { higher } \\
\text { institutions }\end{array}$ & $\begin{array}{l}\text { Ratio of } \\
\text { teachers to } \\
\text { students in } \\
\text { secondary } \\
\text { schools }\end{array}$ & $\begin{array}{l}\text { Ratio of } \\
\text { teachers to } \\
\text { students in } \\
\text { primary } \\
\text { schools }\end{array}$ & $\begin{array}{c}\text { Ratio of } \\
\text { students to } \\
\text { schools at } \\
\text { tertiary } \\
\text { institution } \\
\text { level }\end{array}$ & $\begin{array}{c}\text { Ratio of } \\
\text { students to } \\
\text { schools at } \\
\text { secondary } \\
\text { level }\end{array}$ & $\begin{array}{l}\text { Ratio of } \\
\text { students to } \\
\text { schools at } \\
\text { primary } \\
\text { level }\end{array}$ \\
\hline \multirow{8}{*}{$\begin{array}{l}\text { Disparities } \\
\text { across } \\
\text { cities }\end{array}$} & 2005 & $\begin{array}{l}0.647 \\
\end{array}$ & 0.153 & 0.139 & $\begin{array}{c}0.417 \\
\end{array}$ & 0.028 & 0.161 & 0.469 & 0.019 & 0.044 & 0.466 & 0.017 & 0.020 & 0.030 & 0.015 & 0.029 & 0.110 & 0.030 & 0.129 \\
\hline & 2006 & 0.831 & 0.149 & 0.130 & 0.412 & 0.028 & 0.161 & 0.458 & 0.021 & 0.046 & 0.465 & 0.015 & 0.020 & 0.027 & 0.017 & 0.028 & 0.095 & 0.032 & 0.127 \\
\hline & 2007 & 0.611 & 0.123 & 0.124 & 0.420 & 0.027 & 0.154 & 0.448 & 0.023 & 0.045 & 0.464 & 0.014 & 0.020 & 0.021 & 0.018 & 0.027 & 0.081 & 0.032 & 0.119 \\
\hline & 2008 & 0.584 & 0.109 & 0.115 & 0.408 & 0.028 & 0.162 & 0.439 & 0.025 & 0.043 & 0.458 & 0.015 & 0.021 & 0.017 & 0.019 & 0.024 & 0.081 & 0.033 & 0.126 \\
\hline & 2009 & 0.616 & 0.107 & 0.131 & 0.418 & 0.028 & 0.158 & 0.433 & 0.029 & 0.042 & 0.455 & 0.016 & 0.021 & 0.015 & 0.020 & 0.024 & 0.069 & 0.034 & 0.119 \\
\hline & 2010 & 0.591 & 0.102 & 0.108 & 0.405 & 0.031 & 0.170 & 0.422 & 0.037 & 0.041 & 0.442 & 0.018 & 0.025 & 0.015 & 0.025 & 0.025 & 0.061 & 0.042 & 0.128 \\
\hline & 2011 & 0.509 & 0.080 & 0.105 & 0.381 & 0.036 & 0.166 & 0.392 & 0.038 & 0.043 & 0.414 & 0.018 & 0.026 & 0.017 & 0.016 & 0.023 & 0.072 & 0.034 & 0.120 \\
\hline & 2012 & 0.480 & 0.072 & 0.098 & 0.366 & 0.037 & 0.163 & 0.390 & 0.037 & 0.038 & 0.405 & 0.019 & 0.026 & 0.015 & 0.016 & 0.020 & 0.068 & 0.035 & 0.125 \\
\hline \multirow{8}{*}{$\begin{array}{l}\text { Disparities } \\
\text { within } \\
\text { provinces }\end{array}$} & 2005 & 0.118 & 0.046 & 0.056 & 0.359 & 0.012 & 0.055 & 0.423 & 0.011 & 0.014 & 0.401 & 0.008 & 0.007 & 0.023 & 0.008 & 0.009 & 0.075 & 0.015 & 0.056 \\
\hline & 2006 & 0.046 & 0.035 & 0.051 & 0.356 & 0.011 & 0.056 & 0.419 & 0.012 & 0.014 & 0.406 & 0.008 & 0.007 & 0.019 & 0.010 & 0.010 & 0.060 & 0.016 & 0.057 \\
\hline & 2007 & 0.188 & 0.039 & 0.052 & 0.364 & 0.011 & 0.053 & 0.412 & 0.013 & 0.014 & 0.409 & 0.008 & 0.007 & 0.013 & 0.010 & 0.010 & 0.051 & 0.016 & 0.055 \\
\hline & 2008 & 0.188 & 0.038 & 0.050 & 0.349 & 0.011 & 0.060 & 0.404 & 0.014 & 0.014 & 0.400 & 0.008 & 0.007 & 0.011 & 0.010 & 0.010 & 0.050 & 0.017 & 0.062 \\
\hline & 2009 & 0.179 & 0.039 & 0.042 & 0.362 & 0.011 & 0.055 & 0.405 & 0.015 & 0.014 & 0.406 & 0.008 & 0.007 & 0.009 & 0.011 & 0.010 & 0.039 & 0.018 & 0.060 \\
\hline & 2010 & 0.190 & 0.033 & 0.045 & 0.355 & 0.012 & 0.057 & 0.395 & 0.020 & 0.014 & 0.400 & 0.010 & 0.009 & 0.010 & 0.016 & 0.012 & 0.039 & 0.023 & 0.061 \\
\hline & 2011 & 0.168 & 0.025 & 0.038 & 0.334 & 0.015 & 0.058 & 0.368 & 0.020 & 0.017 & 0.376 & 0.010 & 0.012 & 0.010 & 0.009 & 0.011 & 0.047 & 0.018 & 0.057 \\
\hline & 2012 & 0.147 & 0.027 & 0.039 & 0.325 & 0.015 & 0.057 & 0.368 & 0.019 & 0.014 & 0.366 & 0.009 & 0.013 & 0.009 & 0.010 & 0.010 & 0.049 & 0.018 & 0.058 \\
\hline \multirow{8}{*}{$\begin{array}{l}\text { Disparities } \\
\text { betw een } \\
\text { provinces }\end{array}$} & 2005 & 0.530 & 0.107 & 0.083 & 0.058 & 0.017 & 0.106 & 0.045 & 0.008 & 0.030 & 0.065 & 0.008 & 0.013 & 0.007 & 0.007 & 0.019 & 0.036 & 0.015 & 0.073 \\
\hline & 2006 & 0.785 & 0.114 & 0.079 & 0.056 & 0.017 & 0.105 & 0.039 & 0.009 & 0.032 & 0.059 & 0.007 & 0.013 & 0.007 & 0.007 & 0.018 & 0.034 & 0.016 & 0.070 \\
\hline & 2007 & 0.423 & 0.084 & 0.072 & 0.056 & 0.017 & 0.102 & 0.036 & 0.010 & 0.031 & 0.055 & 0.007 & 0.014 & 0.008 & 0.008 & 0.016 & 0.031 & 0.015 & 0.064 \\
\hline & 2008 & 0.397 & 0.071 & 0.064 & 0.059 & 0.017 & 0.102 & 0.036 & 0.011 & 0.029 & 0.058 & 0.007 & 0.014 & 0.006 & 0.008 & 0.014 & 0.031 & 0.016 & 0.064 \\
\hline & 2009 & 0.437 & 0.068 & 0.089 & 0.056 & 0.018 & 0.102 & 0.028 & 0.014 & 0.028 & 0.049 & 0.008 & 0.014 & 0.006 & 0.009 & 0.014 & 0.031 & 0.016 & 0.060 \\
\hline & 2010 & 0.401 & 0.069 & 0.063 & 0.050 & 0.019 & 0.113 & 0.028 & 0.017 & 0.027 & 0.042 & 0.008 & 0.016 & 0.005 & 0.009 & 0.014 & 0.022 & 0.019 & 0.068 \\
\hline & 2011 & 0.342 & 0.055 & 0.067 & 0.047 & 0.021 & 0.107 & 0.024 & 0.018 & 0.026 & 0.038 & 0.008 & 0.014 & 0.006 & 0.006 & 0.012 & 0.025 & 0.016 & 0.063 \\
\hline & 2012 & 0.333 & 0.045 & 0.059 & 0.041 & 0.022 & 0.106 & 0.022 & 0.018 & 0.023 & 0.039 & 0.010 & 0.013 & 0.006 & 0.007 & 0.010 & 0.019 & 0.017 & 0.068 \\
\hline
\end{tabular}

Note: The denominators of the ratios for which the Theil indices are calculated are indicated in the names of the variables. The sample size is $271-287$ cities at the prefecture level.

Source: Authors' calculations based on the CEIC database. 
41. There are considerable regional differences in government spending on science (Table 17). Disparities in spending per capita on science across cities, while declining during 2010-12, are relatively large (Theil index of 0.48 in 2012), and stem mostly from differences between provinces.

Table 18. Disparities at the county level

Theil indices of inequality

\begin{tabular}{ccccccc}
\hline & \multicolumn{2}{c}{ Disparities across counties } & \multicolumn{2}{c}{ Disparities within provinces } & \multicolumn{2}{c}{ Disparities between provinces } \\
\cline { 2 - 7 } Year & $\begin{array}{c}\text { No of enrolled } \\
\text { students: } \\
\text { primary school }\end{array}$ & $\begin{array}{c}\text { No of enrolled } \\
\text { students: } \\
\text { secondary school }\end{array}$ & $\begin{array}{c}\text { No of enrolled } \\
\text { students: } \\
\text { primary school }\end{array}$ & $\begin{array}{c}\text { No of enrolled } \\
\text { students: } \\
\text { secondary school }\end{array}$ & $\begin{array}{c}\text { No of enrolled } \\
\text { students: } \\
\text { primary school }\end{array}$ & $\begin{array}{c}\text { No of enrolled } \\
\text { students: } \\
\text { secondary school }\end{array}$ \\
\hline 2004 & 0.043 & 0.026 & 0.021 & 0.018 & 0.022 & 0.008 \\
2005 & 0.049 & 0.028 & 0.024 & 0.020 & 0.025 & 0.008 \\
2006 & 0.051 & 0.028 & 0.024 & 0.019 & 0.027 & 0.009 \\
2007 & 0.052 & 0.029 & 0.024 & 0.020 & 0.028 & 0.009 \\
2008 & 0.053 & 0.031 & 0.025 & 0.020 & 0.028 & 0.010 \\
2009 & 0.056 & 0.034 & 0.028 & 0.021 & 0.029 & 0.013 \\
2010 & 0.053 & 0.040 & 0.027 & 0.024 & 0.026 & 0.016 \\
2011 & 0.061 & 0.045 & 0.030 & 0.026 & 0.031 & 0.020 \\
2012 & 0.050 & 0.044 & 0.027 & 0.025 & 0.023 & 0.019 \\
\hline
\end{tabular}

Note: The Theil indices are calculated on per capita data. The sample size varies between 2064 and 2078 counties, not including city districts at the county level.

Source: Authors' calculations based on the CEIC database.

\section{Looking ahead: filling the skills gap and reducing inequalities}

42. Bringing the skills offered in line with market demand and addressing inequalities in education have been recognised and rank high in the Chinese government's priority list. Several measures have been taken to tackle those issues, including in major government documents. The Outline of China's National Plan for Medium and Long-term Education Reform and Development 2010-20 attached high importance to skills and vocational education. More recently, a Plan for Building a Modern Vocational Education System 2014-20 was launched with more details on the implementation. In August 2014, the Ministry of Education issued the Opinion on Piloting a Modern Apprenticeship System, with detailed implementation measures to follow.

43. Recent measures to make higher education more relevant for the market include the pilot Engineering Excellence Training Plan that aims at establishing a mechanism for joint training of engineers by schools and firms. The Plan started in 2010 and covers 1257 undergraduate and 514 graduate majors in 208 higher education institutions. In the three years following the adoption of the Plan, 47000 participants graduated and the overall quality of students and employer satisfaction are said to have increased.

44. Education opportunities are becoming more equal. An increasing number of migrant children are enrolled in public schools or receive vouchers to enrol in private ones. Those remaining in rural areas enjoy better facilities and learning environment owing to a number of initiatives that channel more funds to rural areas. Also, teacher exchanges help filling the gap. In cities, most access routes to the best schools that had been reserved for the privileged have been eliminated and children no longer have to sit for entrance exams to primary and middle schools.

45. A major achievement is the portability of credits across institutions making the switch between vocational and general streams or adult learning possible. Over time, this is likely to make vocational institutions more attractive. 


\section{BIBLIOGRAPHY}

Ball, C. (2009), "Graduate Mobility - Who Goes to Work in Each Region”, available at http://ww2.prospects.ac.uk/cms/ShowPage/p!eXbbbak, accessed on 14 January 2015.

Ministry of Education (2010), Outline of China's National Plan for Medium and Long-term Education Reform and Development 2010-2020.

Ministry of Education (2014), Xiandai Zhiye Jiaoyu Tixi Jiianshe Guihua 2014-2020 (Plan for Building a Modern Vocational Education System).

Ministry of Health, Labour and Welfare (2014), "Heisei 25 Nendo Daigakutou Sotsugyoushano Shuushoku Joukyou Chousa" (Graduate Employment Situation Survey of Heisei 25 Year Graduates).

MyCOS (2014), Jiuye Lanpishu - 2014 Nian Zhongguo Daxuesheng Jiuye Baogao (Blue Book of Employment - 2014 Chinese College Graduates' Employment Annual Report).

OECD (2015), Economic Survey of China, OECD, Paris.

State Council Education Evaluation Committee Office (2014), "2013 Evaluation of Equitable

Development in Compulsory Education", State Education Evaluation Report, No. 2014(1).

State Council and Central Committee of the CCP (2010), National Medium-and Long-term Talent Development Plan 2010-2020.

Zhan, S. (2012), "Zexiao yu Jiaoyu Junhenghua Guanxi de Tantao: Jiyu PISA 2009 de Shizheng Yanjiu" (Relationship between School Choice and Education Equalization: An Empirical Study Based on PISA 2009), Xiandai Jichu Jiaoyu Yanjiu, Vol. 5.

Zhang, T. (2013), “Quyu Jiaoyu Junheng Fazhan - Lichang yu Luxian” (The Balanced Development of Regional Education: Standpoint and Route), Jiaoyu Fazhan Yanjiu, 2013(11). 
ECO/WKP(2015)38

\section{WORKING PAPERS}

The full series of Economics Department Working Papers can be consulted at www.oecd.org/eco/workingpapers

1219. Providing the right skills to all in China - from "made in China" to "created in China" (May 2015) by Margit Molnar and Vincent Koen

1218. Agricultural reforms and bridging the gap for rural China

(May 2015) by Ben Westmore

1217. A snapshot of China's service sector

(May 2015) by Margit Molnar and Wei Wang

1216. Does the post-crisis weakness of global trade solely reflect weak demand?

(May 2015) by Patrice Ollivaud and Cyrille Schwellnus

1215. Estonia: raising productivity and benefitting more from openness

(May 2015) by Andreas Kappeler

1214. Estonia: making the most of human capital

(May 2015) by Andrés Fuentes Hutfilter

1213. The Czech labour market: documenting structural change and remaining challenges

(May 2015) by Sónia Araújo and Petr Malecek

1212. Reforming the Slovak public sector

(April 2015) by Lilas Demmou and Robert Price

1211. Spurring growth in lagging regions in the Slovak Republic

(April 2015) by Lilas Demmou, Gabriel Machlica and Martin Haluš

1210. Skill mismatch and public policy in OECD countries

(April 2015) by Müge Adalet McGowan and Dan Andrews

1209. Labour market mismatch and labour productivity: evidence from PIAAC data

(April 2015) by Müge Adalet McGowan and Dan Andrews

1208. Maintaining an efficient and equitable housing market in Belgium

(April 2015) by Sanne Zwart

1207. Determinants of the low female labour force participation in India

(April 2015) by Piritta Sorsa, Jan Mares, Mathilde Didier, Caio Guimaraes, Marie Rabate, Gen Tang and Annamaria Tuske

1206. Strengthening skill use and school-to-work transitions in the Czech Republic

(April 2015) by Sónia Araújo and Petr Malecek 
1205. Reforming the tax on immovable property: taking care of the unloved (April 2015) by Hansjörg Blöchliger

1204. Taxation and investment in Colombia (April 2015) by Sarah Perret and Bert Brys

1203. Efficiency and contestability in the Colombian banking system (April 2015) by Christian Daude and Julien Pascal

1202. Fiscal decentralisation in Colombia: new evidence regarding sustainability, risk sharing and "fiscal fatigue"

(April 2015) by Guillaume Bousquet, Christian Daude and Christine de la Maisonneuve

1201. Effects of economic policies on microeconomic stability

(April 2015) by Boris Cournède, Paula Garda and Volker Ziemann

1200. The 2013 update of the OECD's database on product market regulation - policy insights for $O E C D$ and non-OECD countries (April 2015) by Isabell Koske, Isabelle Wanner, Rosamaria Bitetti and Omar Barbiero

1199. Improving taxes and transfers in Australia

(April 2015) by Philip Hemmings and Annamaria Tuske

1198. Federal-state relations in Australia

(April 2015) by Vassiliki Koutsogeorgopoulou and Annamaria Tuske

1197. Sharing the fruits of growth with all Mexicans

(April 2015) by Eduardo Olaberriá and Valéry Dugain

1196. What makes Mexicans happy?

(April 2015) by Valéry Dugain and Eduardo Olaberriá

1195. Improving the labour market integration of immigrants in Belgium (March 2015) by Álvaro Pina, Vincent Corluy and Gerlinde Verbist

1194. Raising the potential of the domestically oriented sector in Germany (March 2015) by André Eid and Andrés Hutfilter

1193. Improving transport infrastructure in Russia

(March 2015) by Alexander Kolik, Artur Radziwill and Natalia Turdyeva

1192. Improving the business climate in Russia

(March 2015) by Arthur Radziwill and Yana Vaziakova

1191. Determinants of female entrepreneurship in India (March 2015) by Arnaud Daymard

1190. The changing role of the exchange rate for macroeconomic adjustment (March 2015) by Patrice Ollivaud, Elena Rusticelli and Cyrille Schwellnus 